Hidden European diversity : a new monotypic hoverfly genus (Diptera: Syrphidae: Eristalinae: Rhingiini)

\author{
Vujic, Ante \\ 2019-04
}

Vujic , A , Ståhls , G \& Radenkovic , S 2019 , ' Hidden European diversity : a new monotypic hoverfly genus (Diptera: Syrphidae: Eristalinae: Rhingiini) ' , Zoological journal of the Linnean Society , vol. 185 , no. 4 , pp. 1188-1211 . https://doi.org/10.1093/zoolinnean/zly066

http://hdl.handle.net/10138/307879

https://doi.org/10.1093/zoolinnean/zly066

cc_by_nd

acceptedVersion

Downloaded from Helda, University of Helsinki institutional repository.

This is an electronic reprint of the original article.

This reprint may differ from the original in pagination and typographic detail.

Please cite the original version. 


\title{
Hidden European diversity: a new monotypic hoverfly genus (Diptera: Syrphidae: Eristalinae: Rhingiini)
}

\author{
ANTE VUJIĆ ${ }^{1}$, GUNILLA STÅHLS ${ }^{2}$, AND SNEŽANA RADENKOVIĆ ${ }^{1, *}$ \\ ${ }^{1}$ Department of Biology and Ecology, Faculty of Sciences, University of Novi Sad, Trg Dositeja \\ Obradovića 2, 21000 Novi Sad, Serbia \\ ${ }^{2}$ Zoology Unit, Finnish Museum of Natural History Luomus, PO Box 17, FI-00014 University of Helsinki, \\ Finland
}

Received 5 January 2018; revised 24 August 2018; accepted for publication 2 September 2018

\begin{abstract}
For the first time in more than 30 years, a new European hoverfly genus has been discovered, Katara gen. nov. Its type species Katara connexa sp. nov. (Diptera: Syrphidae) is described from the Pindos Mountains (Greece), and the systematic position of the monotypic taxon within the tribe Rhingiini is analysed using morphological and molecular data. Phylogenetic analyses resolved Katara connexa gen. et sp. nov. as sister taxon to Pelecocera latifrons. We assert based on the molecular phylogenetic results and the morphological distinctness of Pelecocera latifrons that this taxon merits a generic rank, thus we erect the genus Pseudopelecocera gen. nov. and also place Pelecocera persiana in this new genus based on shared characteristics. Based on our results, we place Chamaesyrphus in subgeneric rank and as a sister group to the nominal subgenus Pelecocera. We provide an identification key to the Rhingiini genera. Our phylogenetic analyses recovered all speciose Rhingiini genera as monophyletic and support existence of three main lineages within the tribe: (1) genus Rhingia with two groups, Palaearctic+Neotropical and Afrotropical taxa, (2) genus Cheilosia with its subgenera, and (3) lineage with remaining genera (Pseudopelecocera gen. nov., Katara gen. nov., Ferdinandea, Psarochilosia, Psarus, Portevinia and Pelecocera).
\end{abstract}

ADDITIONAL KEYWORDS: Katara connexa - new genus - new species - Pelecocera latifrons - Pindos Mountains - Pseudopelecocera.

\section{INTRODUCTION}

The tribe Rhingiini (formerly Cheilosiini) comprises the genera Chamaesyrphus Mik, 1895, Cheilosia Meigen, 1822, Ferdinandea Rondani, 1844, Ischyroptera Pokorny, 1887, Macropelecocera Stackelberg, 1952, Pelecocera Meigen, 1822, Portevinia Goffe, 1944, Psarochilosia Stackelberg, 1952, Rhingia Scopoli, 1763, and Psarus Latreille, 1804. Most of these genera are primarily distributed in the Holarctic region (Table 1). The Catalogue of Palaearctic Diptera (Peck, 1988) listed all mentioned genera in the tribe Cheilosiini, except for Psarus that was ascribed to Psarini. Different subtribal classification schemes of the taxa have previously been presented (e.g.

*Corresponding author. E-mail: snezana.radenkovic@dbe.uns. ac.rs

[Version of Record, published online 10 December 2018; http://zoobank.org/urn:lsid:zoobank.org:pub:A8CC9F24937A-4079-A567-A4069DC67D1A]
Thompson, 1972; Shatalkin, 1975), but none has been generally adopted. Phylogenetic relationships of the Rhingiini taxa have been studied by several authors using morphological and/or molecular characters (Rotheray \& Gilbert, 1999; Stuke, 2000; Ståhls et al., 2004). The study by Ståhls et al. (2004) based on both morphological and molecular characters found that the monophyly of the highly speciose genus Cheilosia, comprising well over 400 species primarily distributed in the Holarctic region, was well-supported. Different authors have variously treated Chamaesyrphus as a subgenus of Pelecocera or recognized it as a separate genus (e.g. Thompson \& Rotheray, 1998; Speight, 2014; Mengual et al., 2015a). Ståhls et al. (2004) stated a need to re-address the phylogenetic placement of the species Pelecocera latifrons Loew, 1856 as their phylogenetic analyses did not recover the taxon as a member of the genus Pelecocera (sensu Thompson, 1972). Mengual et al. (2015a) revised the Holarctic genus Pelecocera and described the male of $P$. persiana (Kuznetzov, 
1989). This study treated the Chamaesyrphus taxon as genus, and thus their revision included the taxa Pelecocera tricincta Meigen, 1822, P. latifrons, P. pergandei (Williston, 1884) and P. persiana.

Discovery of specimens of an unknown species from a high altitude locality in central Greece, exhibiting characteristics that clearly identified it as a member of the tribe Rhingiini, initiated the present study on the identity and systematic placement of this taxon. The taxon possesses a very distinctive, apomorphic combination of characters which are not concordant with members of any of the known Rhingiini genera.

Molecular phylogenetic studies of Syrphidae taxa have frequently employed the mitochondrial cytochrome c oxidase subunit I (hereafter COI), nuclear $28 \mathrm{~S}$ and $18 \mathrm{~S}$ ribosomal RNA genes, that proved to be informative for both generic and species levels (e.g. Mengual, Ståhls \& Rojo, 2008, 2015b; Reemer \& Ståhls, 2013; Vujić et al., 2013).

We generated DNA sequences of these standard genes (COI, $28 \mathrm{~S}$ and $18 \mathrm{~S})$ for multiple taxa representing 10 out of the total 11 Rhingiini genera and coded 35 morphological characters for all ingroup Rhingiini taxa and outgroups. The aims of the study are: 1) to evaluate the taxonomy and systematics of the unknown taxon found in Greece and of Pelecocera latifrons using morphological and molecular data, and 2) to resolve their phylogenetic affinities and placements within Rhingiini. We also provide an identification key to all genera of Rhingiini, and an extensive table describing and comparing informative morphological characters for diagnosing all genera.

\section{MATERIAL AND METHODS}

\section{MORPHOLOGICAL STUDIES}

The characters used in the description and drawings employ the terminology established by Speight (1987) and Thompson (1999), in addition to those relating to male genitalia that follow Claussen (2000) and Doczkal (2002). The male genitalia were extracted from dry specimens, cleared by boiling them in water-diluted $\mathrm{KOH}$ pellets, before using acetic acid to neutralize the $\mathrm{KOH}$. Genitalia were stored in microvials containing glycerol. Drawings were made with an FSA $25 \mathrm{PE}$ drawing tube attached to a binocular microscope (Leica MZ16). Photographs were taken using a camera (Leica DFC320) connected to a binocular microscope (Leica MZ16). Morphological characters used in combined molecular and morphological analysis are listed in Supporting information Appendix S2.

\section{MOLECULAR STUDIES}

Specimens used for both morphological and molecular studies (including GenBank accession numbers) are listed in Supporting information Table S1. For the molecular phylogenetic analyses, multiple representatives of all Rhingiini genera were included, except for the rare taxon Ischyroptera bipilosa Pokorny, 1887 because a specimen suitable for DNA analyses was not available. Included species were mainly from the Palaearctic region, with a few representatives from the Afrotropical, Nearctic and Neotropical regions. Some sequences generated by Ståhls et al. (2004) (the 3' part of mtDNA COI and $28 \mathrm{~S} \mathrm{rDNA}$ ) were used in the present study (in boldface in Supporting information Table S1) in addition to new sequences of additional representative species (Supporting information Table S1).

\section{VOUCHER SPECIMENS}

Specimens with a labcode including the acronym MZH are deposited as DNA voucher specimens in the Zoological Museum of the Finnish Museum of Natural History, Helsinki, Finland and specimens are labelled accordingly. The remaining specimens are deposited in collections of the University of Novi Sad, Serbia (FSUNS), California State Collection of Arthropods, Sacramento, California, USA (CSCA; Martin Hauser), Zoologisches Forschungsmuseum A. Koenig Bonn, Germany (ZFMK) and the specimen of Ischyroptera bipilosa that is from the National Museum of Natural History, Smithsonian Institution, Washington DC, USA (USNM) (Supporting information Table S1).

\section{LABORATORY PROCEDURES}

DNA was extracted from 1-3 legs of dry-pinned or ethanol-preserved specimens using the Nucleospin Tissue DNA extraction kit (Machery-Nagel, Düren, Germany) following the manufacturer's protocols and then resuspended in $50 \mu$ l of ultra-pure water.

PCR reactions were carried out using GE Readyto-Go PCR beads in $25 \mu \mathrm{l}$ reaction aliquots containing $2 \mu \mathrm{l}$ DNA extract, $1 \mu \mathrm{l}$ of each primer (at $10 \mathrm{pmol} / \mu \mathrm{l})$ and ultrapure water. Thermocycler conditions were initial denaturing at $95^{\circ} \mathrm{C}$ for $2 \mathrm{~min}, 29$ cycles of $30 \mathrm{~s}$ denaturing at $94^{\circ} \mathrm{C}, 30 \mathrm{~s}$ annealing at $49^{\circ} \mathrm{C}, 2 \mathrm{~min}$ extension at $72^{\circ} \mathrm{C}$, followed by a final extension of $8 \mathrm{~min}$ at $72^{\circ} \mathrm{C}$. The universally conserved primers used for amplifying and sequencing the $C O I$ fragments were LCO1490 (5'-GGTCAACAAATCATAAAGATATTGG-3') and $\mathrm{HCO}-2198$ (5'-TAAACTTCAGGGTGACC AAAAAATCA-3') (Folmer et al., 1994) for the 5'region of COI (hereafter COIa), and the forward primer C1-J2183 (5'-CAA CAT TTA TTT TGA TTT TTT GG-3') (alias JERRY) and reverse primer TL2-N-3014 (5'TCC AAT GCA CTA ATC TGC CAT ATT A-3') (alias PAT) (Simon et al., 1994) for the 3'region (hereafter COIb). The D2-3 region of the nuclear ribosomal 28S rRNA gene was amplified with the forward 
primer F2 (5'-AGA GAG AGT TCA AGA GTA CGT G-3') and reverse primer 3DR (5'-TAG TTC ACC ATC TTT CGG GTC-3'). The nuclear ribosomal 18S rRNA gene was amplified with the forward primer 2F (5'-AGGGTTCGATTCCGGAGAGGGAGC-3') and the reverse primer b2.9 (5'-TATCTGATCG CCTTCGAACCTCT-3').

\section{SEQUENCE ALIGNMENT}

The gap-free sequences of the protein-coding $C O I$ gene were assembled manually and trimmed to equal lengths to avoid missing data. The alignment of the $28 \mathrm{~S}$ and $18 \mathrm{~S}$ rDNA fragments was carried out using the E-INS-I strategy as implemented in MAFFT (Katoh et al., 2005; Katoh, Asimenos \& Toh, 2009) using the CIPRES Science Gateway (Miller, Pfeiffer \& Schwartz, 2010) (http://www.phylo.org/sub_sections/ portal/). The E-INS-I strategy was chosen because it is optimized for a small-scale alignment and recommended for sequences with multiple conserved domains and gaps, such as rRNA genes (Katoh et al., 2009). The length of the obtained (unaligned) fragments of $18 \mathrm{~S}$ among ingroup taxa varied between $672-676 \mathrm{bp}$, and the length of the D2-D3 region of 28S between 566-587 bp.

\section{PhyLOGENETIC ANALYSIS}

We analysed the data as follows: 1) data set of 50 taxa including all the taxa for which $C O I$ sequences were available, (all COI analysis), 2) data set of 43 taxa for combined sequences of three genes (COI, 28S, 18S) (three-genes analysis) and 3) data set of 43 taxa for combined sequences of three genes and morphological data (combined analysis).
Eumerus flavitarsis Zetterstedt, 1843 (Syrphidae: Eristalinae: Merodontini) was used to root the trees, and six other Eristalinae taxa were included as additional outgroups (Supporting information Table S1). The COI only, three-genes and combined datasets were analyzed using maximum likelihood methods carried out with RAxML vs 8.2.10 HPC2 on XSEDE (Stamatakis, 2014) using CIPRES Portal Web Server http://www.phylo.org/sub_sections/portal/ on Cipres Science Gateway (Miller et al., 2010).

RAxML analyses of DNA data and combined datasets used the GTR + G model for the DNA data and the MK model (Lewis, 2001) for morphological data. The option to conduct rapid bootstrapping and thorough search for the best-scoring ML-tree in a single program run was selected. Branch support was calculated with 1000 non-parametric bootstrap replicates. Trees were visualized and rooted using MEGA vs. 6 (Tamura et al., 2013).

\section{RESULTS}

\section{MOLECULAR DATA}

The mtDNA COI dataset (concatenated COIa and COIb) comprised 1344 nucleotides for 43 Rhingiini taxa and seven outgroups. Taxa for which we had only COI data are Macropelecocera sanguinea Doczkal, 2002 (only COIb), Pelecocera willistoni Snow, 1895 (only COIb), Pelecocera (Chamaesyrphus) sp. A and sp. B, Portevinia dispar (Hervé-Bazin, 1929) and Rhingia trivittata Curran, 1929 (see Supporting information Table S1). The length of the aligned 18S dataset was $680 \mathrm{bp}$, and that of the $28 \mathrm{~S}$ dataset was $614 \mathrm{nt}$. The three-genes dataset (COI and the aligned $28 \mathrm{~S}$ and 18S sequences) comprised 2638 nucleotide positions,

Table 1. Review of taxa belonging to the tribe Rhingiini

\begin{tabular}{|c|c|c|}
\hline Genus & Number of species $(\sim)^{b}$ & Distribution \\
\hline Cheilosia Meigen, 1822 & 446 & Holarctic, Oriental, Neotropic \\
\hline Ferdinandea Rondani, 1844 & 17 & Holarctic, Oriental \\
\hline Ischyroptera Pokorny, $1887^{\mathrm{a}}$ & 1 & Palaearctic \\
\hline Katara Vujić \& Radenković gen. nov. & 1 & Palaearctic \\
\hline Macropelecocera Stackelberg, 1952 & 4 & Palaearctic \\
\hline Pelecocera Meigen, 1822 & 11 & Holarctic, Oriental \\
\hline \multicolumn{3}{|l|}{ syn. nov. Chamaesyrphus Mik, 1895} \\
\hline Pseudopelecocera Vujić \& Radenković gen. nov. & 2 & Palaearctic \\
\hline Portevinia Goffe, 1944 & 4 & Palaearctic, Oriental \\
\hline Psarochilosia Stackelberg, 1952 & 1 & Palaearctic \\
\hline Psarus Latreille, 1804 & 1 & Palaearctic \\
\hline Rhingia Scopoli, 1763 & 47 & Holarctic, Oriental, Afrotropic, Neotropic \\
\hline
\end{tabular}

a generic status still unclear (unresolved)

${ }^{\mathrm{b}}$ numbers are from Thompson, Rotheray, Zumbado (2010) and Ståhls \& Barkalov (2017) 


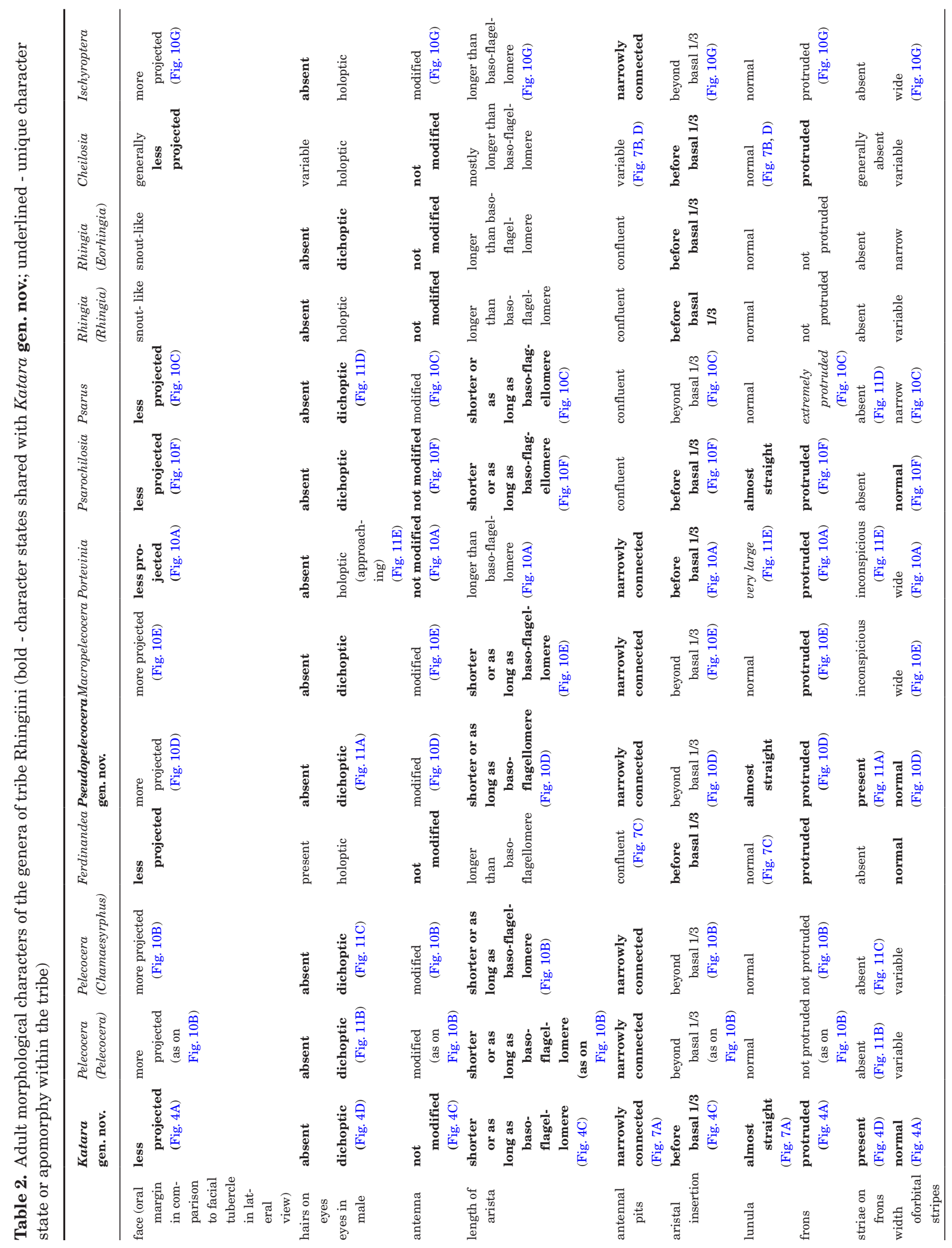




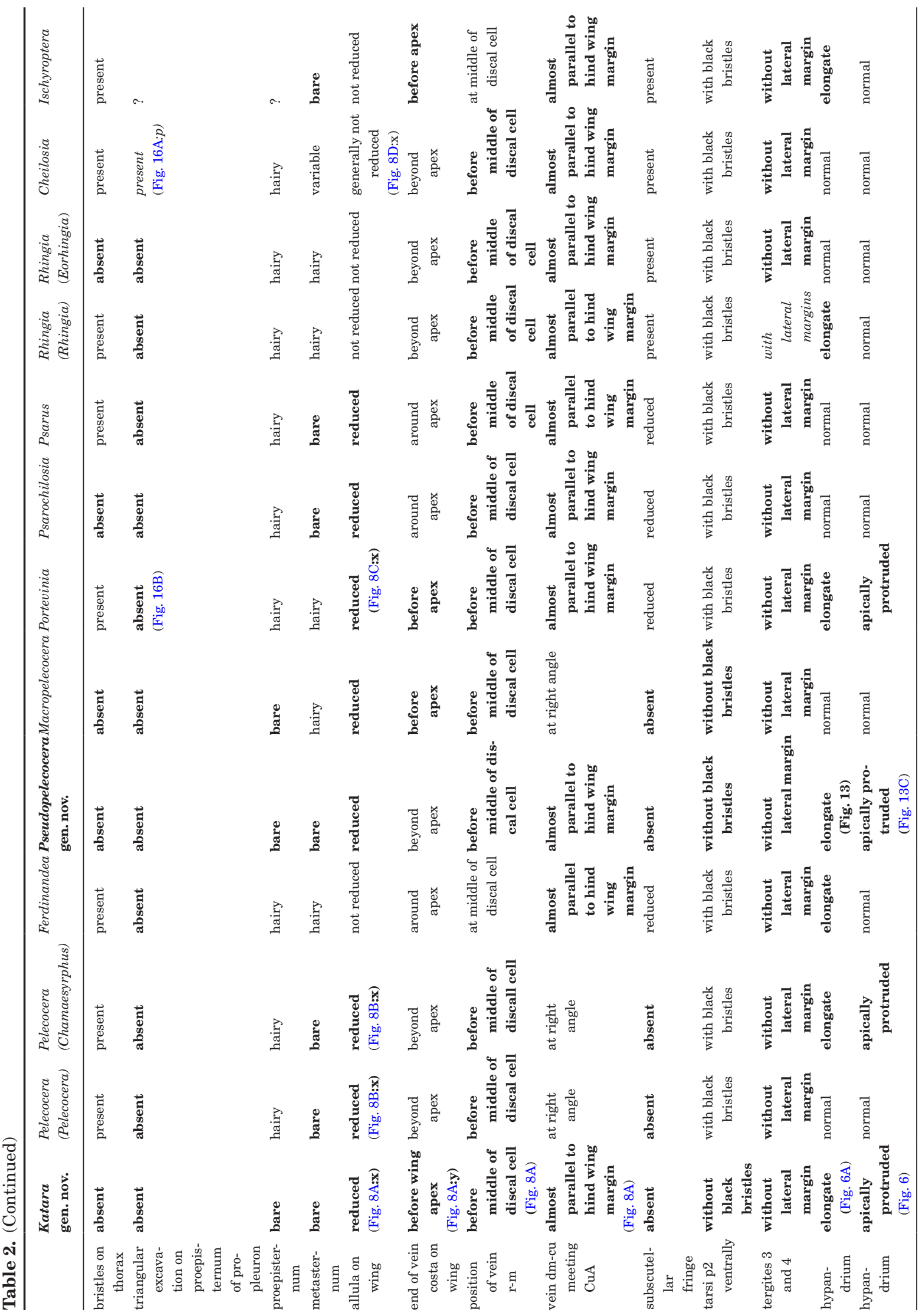




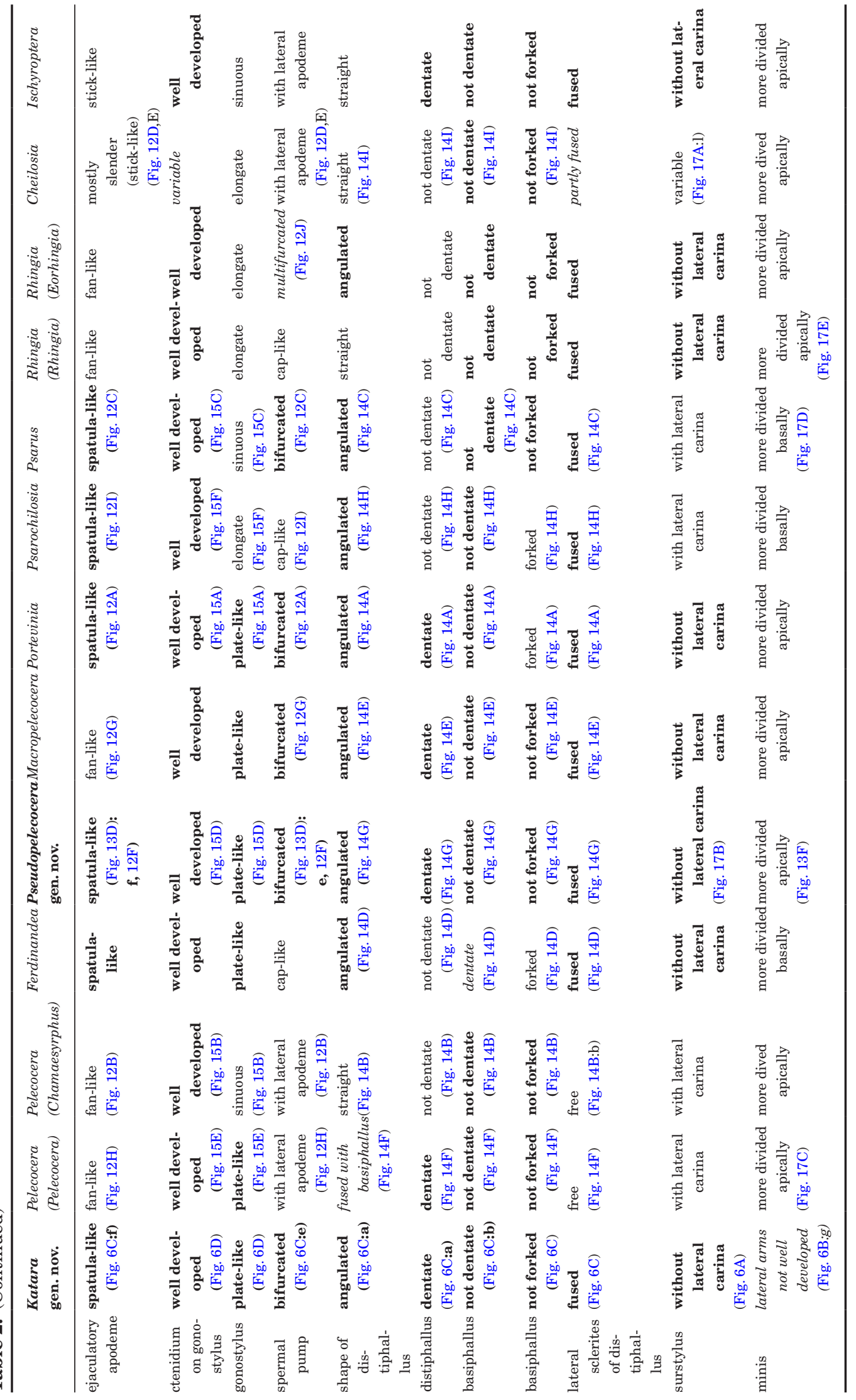


and combined dataset comprised 2638 nucleotide and 35 morphological characters (Supporting information Appendix S2) for 36 Rhingiini taxa and the seven outgroups.

\section{MoRPHOLOGICAL STUDIES}

A differential diagnosis for all Rhingiini genera is presented Table 2, where apomorphic character states for each genus are highlighted. Based on our study of the morphology of the unknown taxon, it clearly belongs to the tribe Rhingiini. Due to its overall morphological and molecular uniqueness the new taxon merits generic rank and here we describe the new genus Katara gen. nov.

\section{Phylogenetic ANALYSES}

The best fitting log likelihood obtained in the separate ML analysis of the COI-only data was -13740.9050 (Fig. 1). The separate ML analysis of the COI only data resolved the Rhingiini taxa in two large groups, one comprising (Macropelecocera $+($ Rhingia + Cheilo sia)) and another group with Katara gen. nov. and Pseudopelecocera gen. nov. resolved as sister group to the remaining Rhingiini taxa. The bootstrap support for (Macropelecocera+ (Rhingia+Cheilosia)) was $<50 \%$, and the support value for the second group was also low (66\%) (Fig. 1). The focal taxa of this study, Katara gen. nov. and Pseudopelecocera gen. nov., were resolved together with moderate support (86\%). The $($ Ferdinandea $+($ Psarochilosia + Psarus $))$ group was recovered with high bootstrap support (95\%). The Nearctic taxon Pelecocera willistoni was resolved as sister to the (Pelecocera s.l. + Portevinia) with moderate support. The genus Portevinia was resolved as sister group to the Palaearctic peleocerines. The genus Rhingia was resolved in two groups, one comprising only taxa with Afrotropical distributions including Rhingia (Eorhingia) cuthbertsoni Curran, 1939, and the other clade comprising the remaining taxa with Neotropical and Palaearctic distribution. For several taxa we had obtained only partial mtDNA COI sequences and no $28 \mathrm{~S}$ nor $18 \mathrm{~S}$ rRNA data, e.g. Macropelecocera sanguinea and Pelecocera (Chamaesyrphus) sp. A + sp. B, thus we do not discuss nor evaluate the placements of these taxa based on the $C O I$ gene trees. In the following we mainly discuss the ML trees of the three-genes and combined data analyses.

The best fitting log likelihood for the RAxML analysis of the three-genes dataset was -18653.626726, and for combined data analysis -19200.415494 (Figs 2, 3).

The topologies of the ML analysis of the threegenes data and the combined data were almost identical, only resolving Portevinia with different placements. The first ingroup node (first dichotomy) of the ML trees resolves the Rhingiini taxa in two large clades, one clade with Rhingia + Cheilosia and the other clade including the remaining Rhingiini taxa. The bootstrap support for the Rhingia + Cheilosia clade in three genes analysis was $<50 \%$ and in combined analysis $68 \%$, and the support value for the other clade was $89 \%$ and $99 \%$, respectively (Figs 2, 3). For the genus Cheilosia the analysis included only 1-3 representatives for most of the described subgenera and the present analyses do not constitute a test of the monophyly of the subgenera, but we found that taxa either placed in the subgenera Eucartosyrphus or Taeniocheilosia were not resolved as monophyletic.

The focal taxa of the present study, Katara gen. nov. and Pseudopelecocera gen. nov., were placed together in the $C O I$ gene tree, and also resolved as sister taxa in both the three genes and the combined analyses with high bootstrap support, 92\% (Fig. 2) and 100\% (Fig. 3), respectively.

\section{DESCRIPTION}

FAMILY SYRPHIDAE LATREILLE, 1802

Tribe Rhinginn Meigen, 1822

Genus KataRA VuJIĆ \& RADENKOVIĆ GEN. NOV. (FIGS 4-8)

The taxon shares the following adult morphological characters with all Rhingiini taxa: pilose postpronotum; two-segmented aedeagus of male genitalia; face with well-defined parafacia; antenna shorter than head; wing: cell $\mathrm{R} 4+5$ acute, with long petiole; anterior crossvein $(\mathrm{r}-\mathrm{m})$ before middle of cell DM (but r-m at middle position in Ferdinandea); upper outer cross vein $\left(\mathrm{M}_{1}\right)$ more or less straight; vein $\mathrm{R}_{4+5}$ almost straight.

Diagnosis: Katara Vujić \& Radenković gen. nov. possesses a unique combination of character states that clearly discriminates it from all other Rhingiini genera: eye dichoptic in both sexes (Fig. 4D, E) and abdomen distinctly broader than thorax in both sexes (1.3-1.4 times wider than thorax) (Fig. 5C-F); basoflagellomere small, rounded, with a short, slightly thickened arista almost as long as the length of antenna (Fig. 4C), proepisternum and proepimeron bare of pilosity in both sexes; and male genitalia with elongated surstylus and epandrium (Fig. 6A, B). Other generic diagnostic characters that discriminate Katara gen. nov. from other Rhingiini genera are: face not protruded (Fig. 4A); frons protruded (Fig. 4A) with transverse striae (Fig. 4D); eye bare; antennal pits narrowly connected (Fig. 7A); the ventral margin of lunula is almost straight without a medial process 


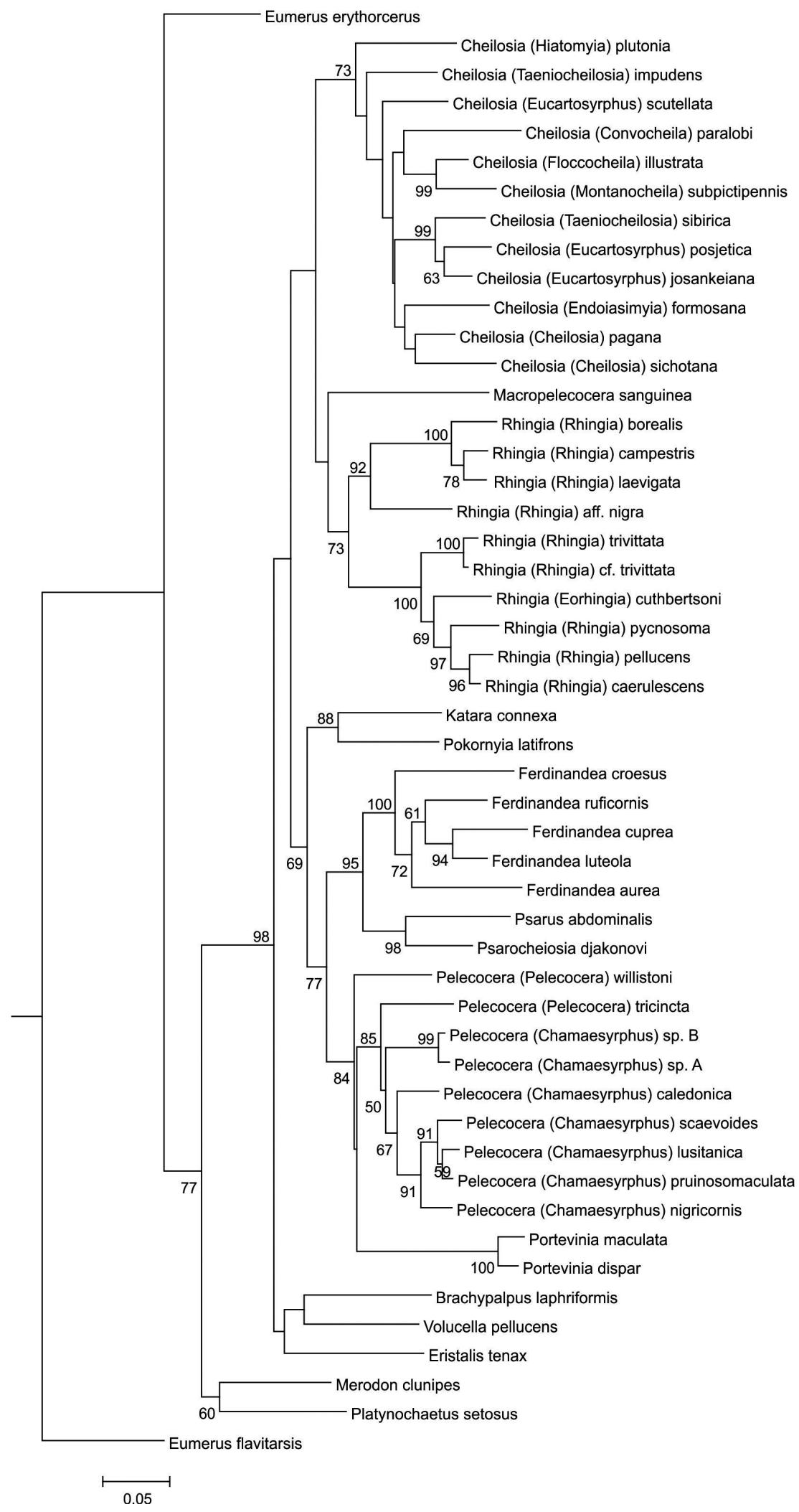

Figure 1. RAxML likelihood tree of mtDNA COI sequences, with bootstrap values $>50 \%$ indicated above branches. 


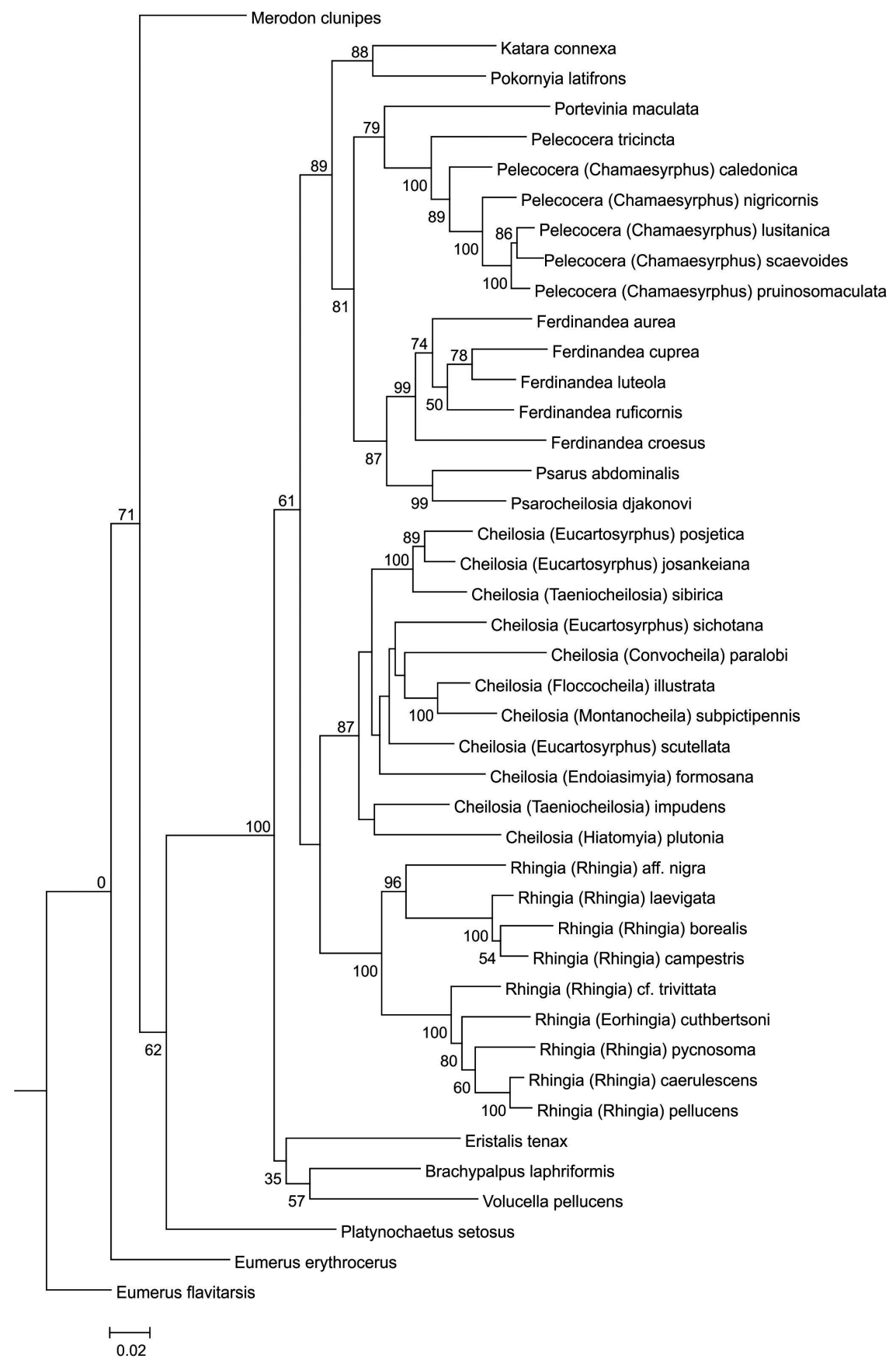

Figure 2. RAxML likelihood tree of combined mtDNA COI, nuclear $28 \mathrm{~S}$ and $18 \mathrm{~S}$ sequences, with bootstrap values $>50 \%$ indicated above branches.

(Fig. 7A); thorax without bristles; metasternum bare; alula reduced (Fig. 8A:x); costal vein ending before wing apex (Fig. 8A:y); anterior crossvein (r-m) placed before mid of cell DM (Fig. 8A); subscutellar fringe absent; tarsomeres of mesolegs ventrally without black bristles; male genitalia with hypandrium apically protruded (Fig. 6), ejaculatory apodeme spatulate (Fig. 6C:f), gonostylus plate-like (Fig. 6D), ctenidium on gonostylus well developed (Fig. 6D), spermal pump bifurcated (Fig. 6C:e), distiphallus angulated (Fig. 6C:a) and dentate (Fig. 6C:a), lateral sclerites of distiphallus fused (Fig. 6C), surstylus without 


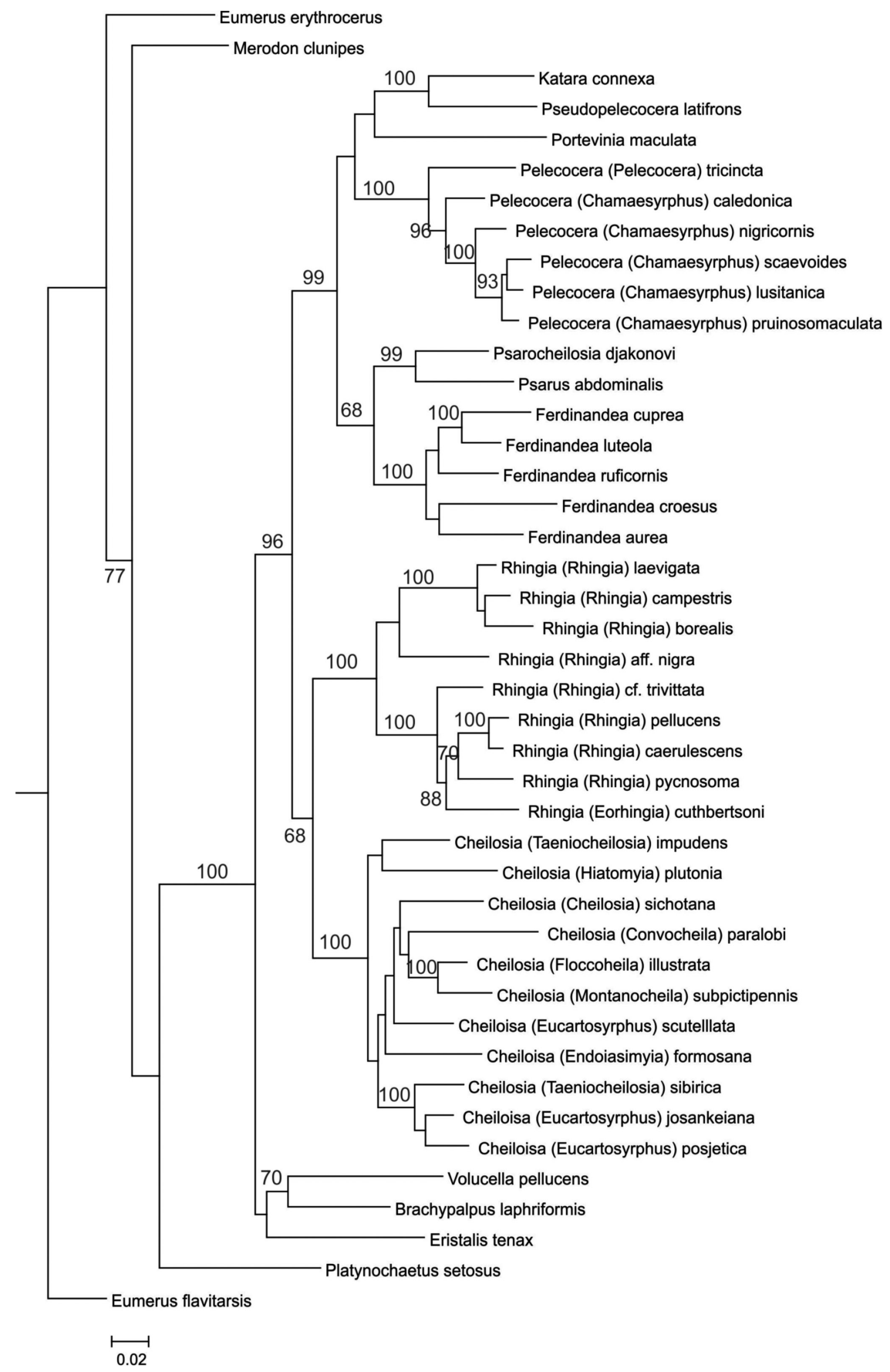

Figure 3. RAxML likelihood tree of combined mtDNA COI, nuclear 28S, $18 \mathrm{~S}$ sequences, and morphological data with bootstrap values $>50 \%$ indicated above branches.

lateral carina (Fig. 6A), lateral arms of minis not well developed (Fig. 6B:g).

Etymology: The new genus is named based on type locality, an area between Katara pass and Kampos
Despoti, in PindosMountains, central Greece. Word 'Katara' is latinized from the Greek word 'Kataras'. The name is to be considered as feminine. It means 'curse' in Greek language, indicating the dangerous high mountain pass. 


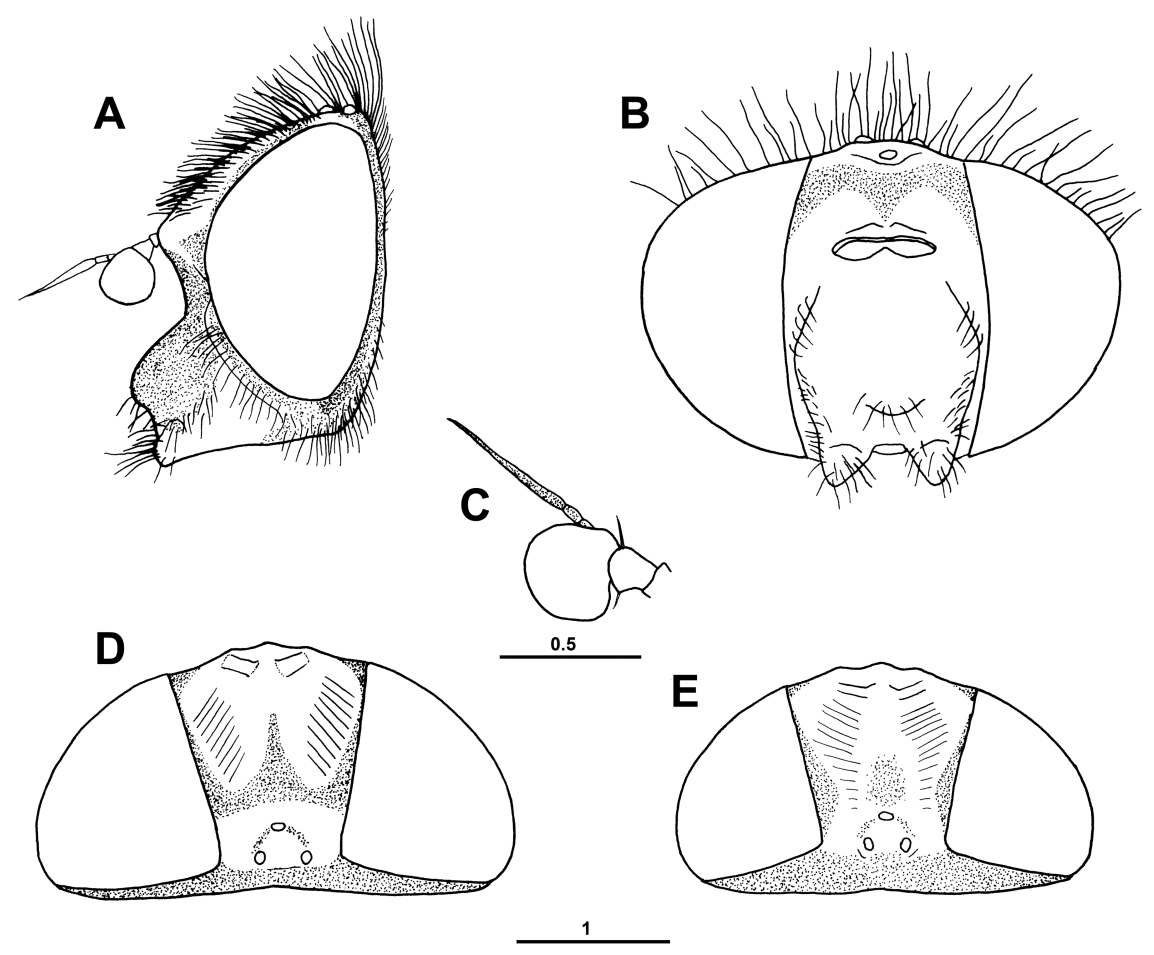

Figure 4. Katara connexa Vujić \& Radenković sp. nov. A, male head, lateral view; B, male head, anterior view; C, male antenna, inner view; D, male head, dorsal view; E, female head, dorsal view. Scale in mm.

\section{KATARA CONNEXA VUJIĆ \& RADENKOVIĆ SP. NOV.}

Type-material: Holotype, ô, GREECE; Pindos Mountains, Kampos Despoti, 39.8028N 21.2721E, 1470.5 m.a.s.l., 15.v.2011, A. Vujić (MZH; http:// id.luomus.fi/GJ.2035).

Paratypes, GREECE: 1 ot, Pindos Mountains, Kampos Despoti, 39.8028N 21.2721E, 1470.5 m., 20.v.1997, (S. Radenković) (FSUNS); 2 \%, (S. Šimić), 15.v.2011, 11 o, 7 ㅇ (A. Vujić) (FSUNS); 3 ơ, Katara Pass, 39.7968N, 21.2292E, $1717 \mathrm{~m}, 26 . v .2012$, (A. Vujić) (FSUNS).

Size ( $n=16$ o, 9 o): body length $8.8-9.1 \mathrm{~mm}$, wing length: 7.3-7.5 mm.

Diagnosis: Shiny, black species with broad, oval abdomen (Fig. 9).

Description of male: Head (Fig. 4A-D). Antenna (Fig. 4C) dark brown with gray pollinosity. Basoflagellomere small, rounded, 0.85 times longer than wide. Arista inserted dorsally at the basal 1/3 of basoflagellomere, thickened in basal $1 / 2$, about as long as antenna (1.2 times longer). Antennal pits almost separated by a cuticular extension of the face (Fig. 4B). Lunula wide (0.54 times width of frons), with an almost straight posterior margin except for a notch medially. Eyes bare, separated (Fig. 4D). Frons broad (0.4 times width of head), with transverse rugosity on lateral parts and with very rough punctuation; partly pollinose (in front of ocellar triangle and along eye margins, but lacking on rugose areas) (Fig. 4D). Most of the vertex non-pollinose, except on posterior part. Occiput entirely gray pollinose. Ocellar triangle equilateral (Fig. 4D). In contrast to the black colour of the whole head, there is a light brown narrow line dorsally along eye margin. Face below antennae concave, with well-developed facial tubercle and parafacia (Fig. 4A); gray pollinose, except for shiny lateral stripes in lower parts (Fig. 9). Long hairs on parafacia; lower part of face and mouth edge are mainly pale, as for postcranium, whereas pilosity of the frons, vertex and occiput is mainly black.

Thorax (Fig. 5A, C). Mesonotum shiny, with fine punctuation, except for three gray pollinose longitudinal stripes (two wider lateral stripes and one narrow central) reaching the level of the transverse suture (Fig. 5C). Hairs on mesonotum long (Fig. 5A) and predominantly black, with some intermingled light yellow ones; without strong bristles. Pleurae gray pollinose, with posterior anepisternum and anterior anepimeron covered with black hairs, katepisternum with pale hairs; dorsal and ventral hair patches on katepisternum widely separated; the following areas lack hairs: anterior anepisternum, proepimeron, katepimeron, posterior anepimeron, meron and katatergum. Metasternum bare. Median postnotal sclerite of mesonotum gray pollinose except for shiny triangular area extending from central part to 
A

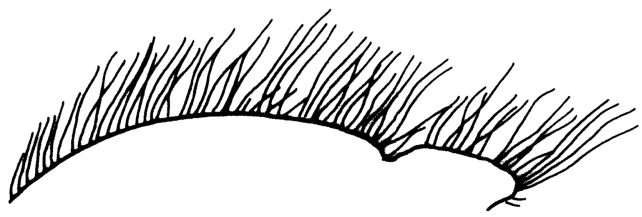

B

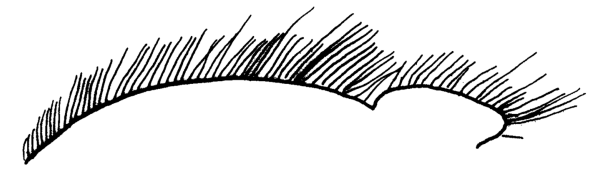

1
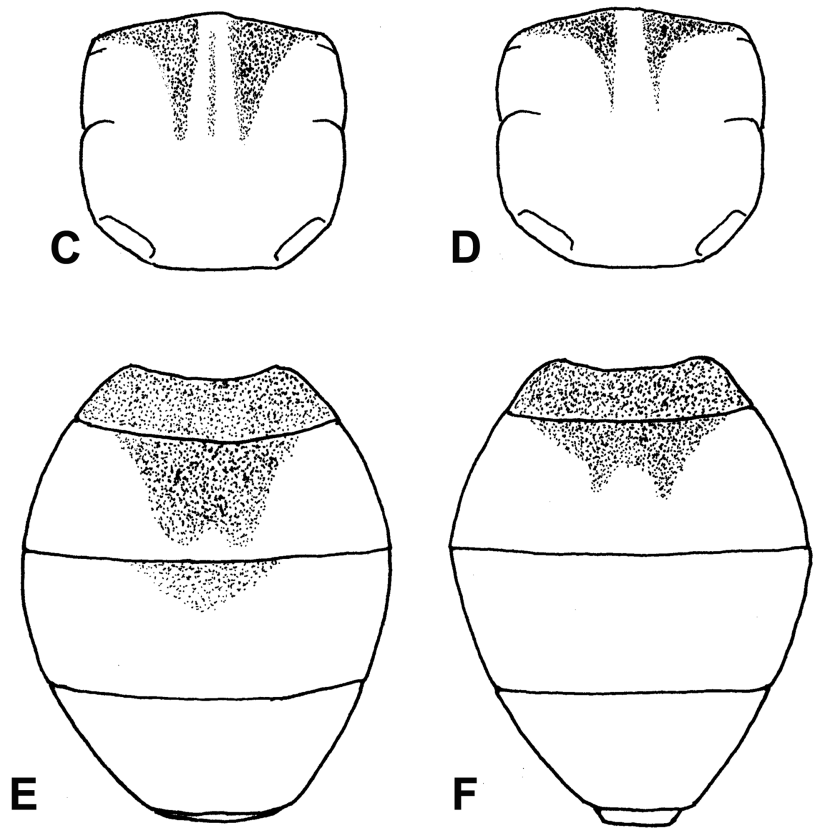

1

Figure 5. Katara connexa Vujić \& Radenković sp. nov. A, male mesonotum, lateral view; B, female mesonotum, lateral view; C, male mesoscutum, dorsal view; D, female mesoscutum, dorsal view; E, male abdomen, dorsal view; F, female abdomen, dorsal view. Scale in $\mathrm{mm}$.

posterior margin. Wing brown hyaline, with black veins; completely covered with dense and strong microtrichia. Alula very narrow (Fig. 8A:x); vein $R_{4+5}$ meets costal vein before apex of wing (Fig. 8A:y); upper outer crossvein (M1) joins vein $R_{4+5}$ at an angle of $80^{\circ}$ (Fig. 8A:M1). Calypter yellow, with some black marginal hairs. Halter pale-brownish. Legs black, except for pale apex of femora and basal 1/2-1/3 of pro- and mesotibiae, and basal 1/3-1/4 of metatibia. Hairs on legs a mix of black and light yellow (pale hairs predominantly on anterior part of pro- femur and tibia, basal 1/4 of mesofemur, posteriorly on metafemur, ventral part of meso- and meta- tibiae, and on all tarsi).
Abdomen (Fig. 5E) broad and oval; clearly broader than thorax at the level of posterior margin of tergite 2 . Tergites and sternites shiny black, except for dull gray pollinose zones on tergites 1-3 (almost whole of tergite 1 , central area on tergite 2 in the form of an inverted trapezoid ending slightly before posterior margin, and a small triangular area antero-medially on tergite 3) (Fig. 5E); punctuation on tergites fine as on mesonotum. Abdominal hairs erect (except adpressed hairs on dull areas of tergites 1 and 2), predominantly pale, except for some black hairs on posterior 1/2 of tergites 3 and 4 and on pregenital segments; pale-haired parts can have a few intermingled black hairs. 

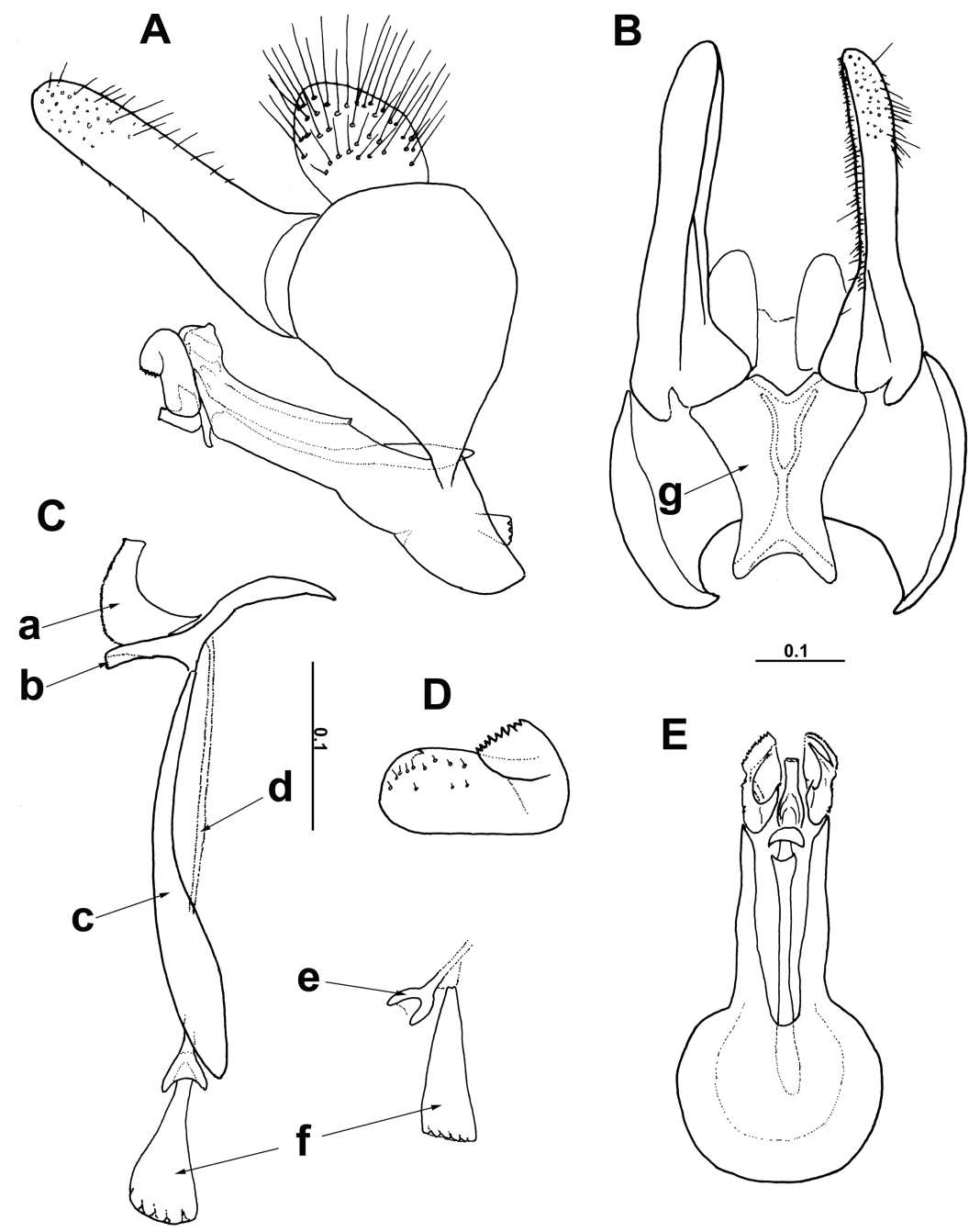

Figure 6. Katara connexa Vujić \& Radenković sp. nov. A, male genitalia, lateral view; B, epandrium, ventral view; C, aedeagus with phallapodeme, lateral view; $\mathrm{D}$, gonostylus, lateral view; E, hypandrium, ventral view. Abbreviations: a, distiphallus; b, basiphallus; c, phallapodeme; d, ejaculatory duct; e, spermal pump; f, ejaculatory apodeme; g, minis. Scale in $\mathrm{mm}$.

Male genitalia (Fig. 6): hypandrium elongated, especially distally extended (Fig. 6A); gonostylus plate-like, with developed ctenidium (Fig. 6D); distiphallus dentate, in the form of an angulated tubus (Fig. 6C:a); spermal pump bifurcated (Fig. 6C:e); ejaculatory apodeme small, in the shape of a narrow spatula (Fig. 6C:f); surstyli elongated (Fig. 6A, B); minis fused, only slightly divided apically and concave ventrally (Fig. 6B:g).

Description of female: Very similar to male, except for the following characters: basoflagellomere and arista reddish-brown, except for dark apical part of arista; frons slightly broader ( 0.42 times width of head), less pollinose in central part (Fig. 4E), covered with shorter pale hairs; hairs on thorax predominantly pale; mesoscutum with shorter hairs (Fig. 5B), less pollinose (only two short, narrow longitudinal stripes present) (Fig. 5D); legs predominantly pale-haired; apex of femora and basal and distal parts of tibiae paler; tergites with smaller pollinose areas (tergite 3 without pollinosity) (Fig. 5F); abdominal hairs predominantly pale, except for a few black hairs on the last segments.

Etymology: The new species is named according to the Latin word 'connexa' indicating the connection of the taxon to the other taxa of the tribe based on its characters. It is the participle of the verb 'connecto' in the nominative singular and agrees in feminine gender with the corresponding genus name.

Distribution: The specimens of Kataria connexa sp. nov. were collected at $1300-1700 \mathrm{~m}$ altitude in the Pindos Mountains of Central Greece. This area belongs 

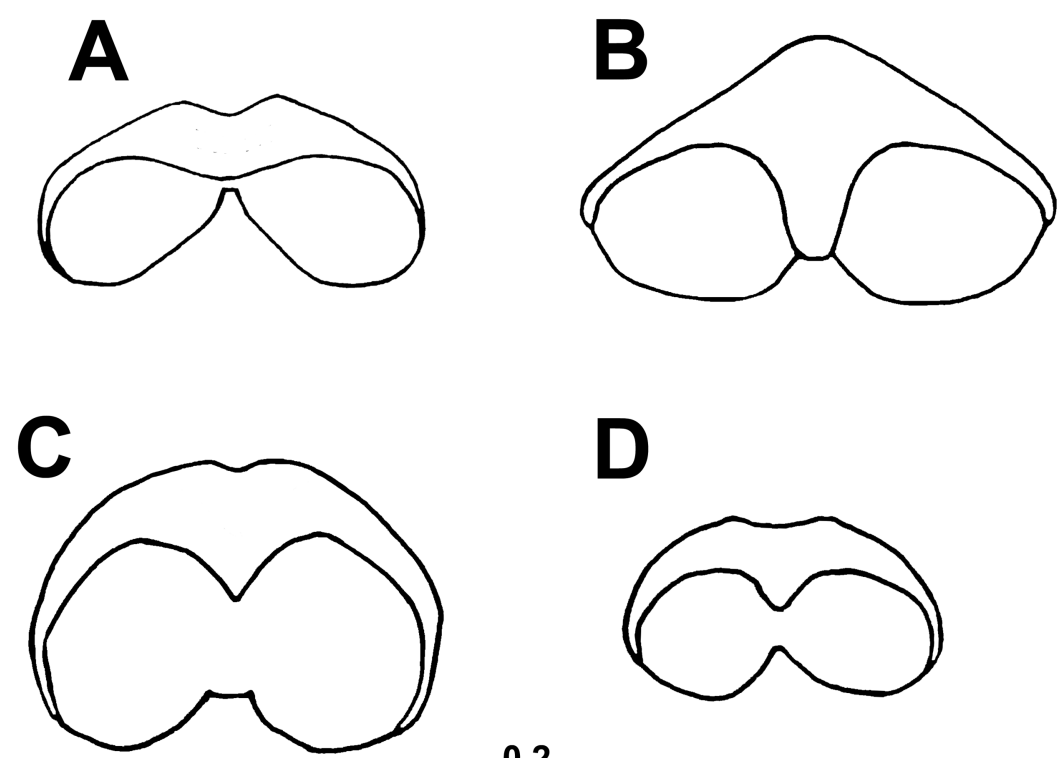

D

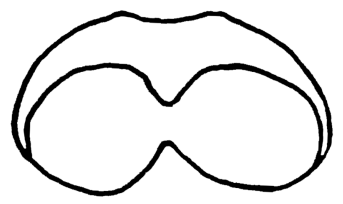

0.2

Figure 7. Antennal pits and lunulae. A, Katara connexa Vujić \& Radenković sp. nov.; B, Cheilosia illustrata (Harris, 1780); C, Ferdinandea cuprea (Scopoli, 1763); D, Cheilosia (Taeniocheilosia) nigripes (Meigen, 1822). Scale in mm.

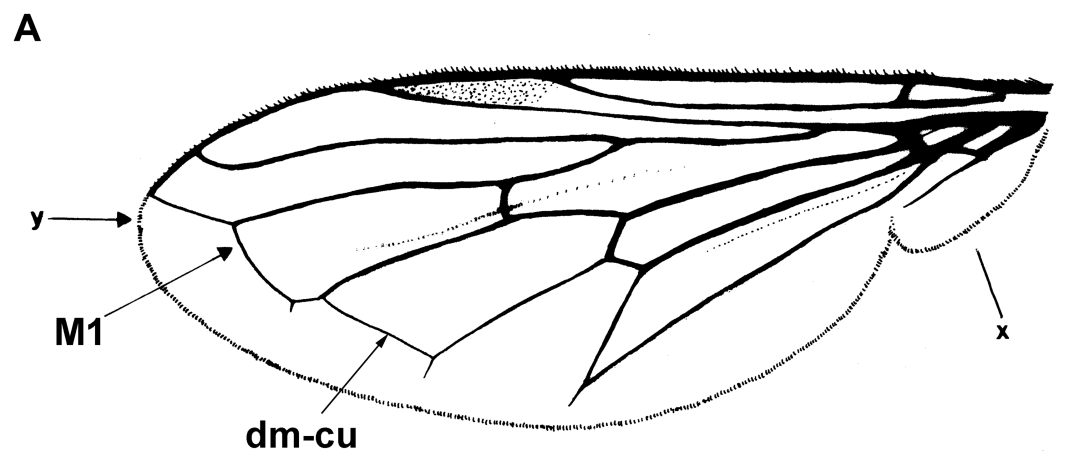

B

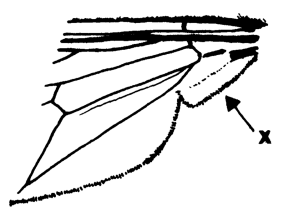

C

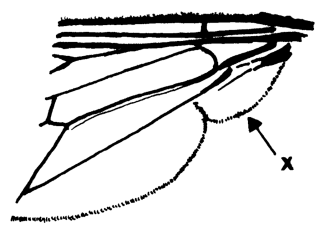

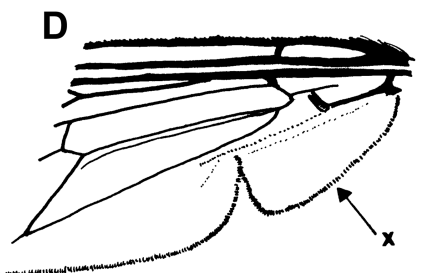

Figure 8. Wing. A, Katara connexa Vujić \& Radenković sp. nov.; B, Pelecocera sp.; C, Portevinia sp.; D, Cheilosia sp. Abbreviations: $\mathrm{x}$, alula; $\mathrm{y}$, apex; $\mathrm{M}_{1}$, upper outer cross vein; $\mathrm{dm}$-cu, lower outer cross vein. Scale in $\mathrm{mm}$.

to the Oro-Mediterranean mountain biome that is rich in pre-glacial habitats and many pre-glacial relict plant and animal taxa. The species Cheilosia katara Claussen et Vujić, 1993, an endemic (relict) species occurring only at Pindos, was described by Claussen \&Vujić (1993) from the same locality (Katara Pass, $1300 \mathrm{~m}$ ). These taxa are only known from relict coniferous forests with Pinus heldreichii H. Christ and Pinus nigra J. F. Arnold subsp. pallasiana (Lamb.) Holmboe.
PSEUDOPELECOCERA VUJIĆ \& RADENKOVIĆ GEN. NOV.

Type: Pelecocera latifrons Loew, 1856: 46; Mengual et al. (2015a) (lectotype des.).

The phylogenetic analyses of both the three-genes and combined data (and also separate analysis of COI gene tree) agreed with the results of Ståhls et al. (2004) in not resolving the Pelecocera latifrons taxon in the Pelecocera sensu lato (sg. Chamaesyrphus + Pelecocera s. str.) clade. 
Morphological characters (listed in Table 2) confirm its distinctness from Pelecocera and Chamaesyrphus. For Pelecocera latifrons, here we erect the new genus Pseudopelecocera Vujić \& Radenković gen. nov. We also place the species Pelecocera persiana in the new genus Pseudopelecocera based on descriptive data and illustrations given in Kuznetzov (1989) and Mengual et al. (2015a), as morphological characters agree well with those of $P$. latifrons. Morphological closeness between these two taxa was previously noted by Doczkal (2002).

Diagnosis: Basoflagellomere large, triangular, with a thick dorso-apical arista (Fig. 10D); eye dichoptic in both sexes; frons wide (as wide as eye), with distinct transversal striae (Fig. 11A); dorsal margin

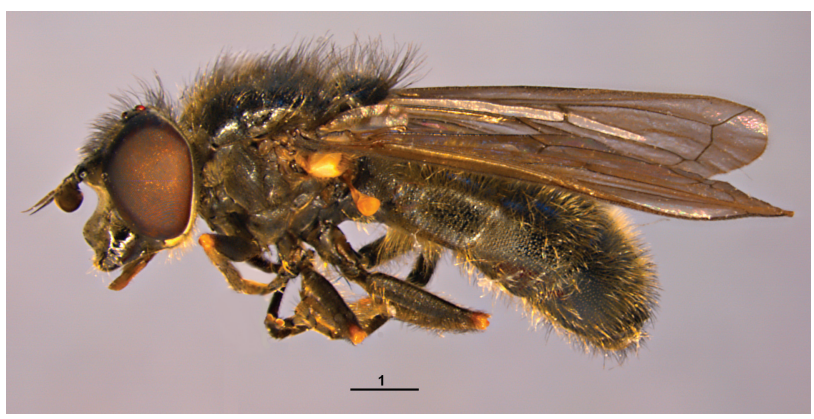

Figure 9. Katara connexa Vujić \& Radenković sp. nov., male, lateral view. Scale in $\mathrm{mm}$. of lunula almost straight; no thoracic bristles; bare proepisternum; mesotarsi without black bristles ventrally; vein dm-cu almost parallel to hind margin; spermal pump bifurcated (Fig. 12F); ejaculatory apodeme in the shape of a spatula (not fan- or sticklike) (Fig. 12F); distiphallus angulated and not fused with basiphallus (Fig. 13D:a); lateral sclerites of distiphallus fused; surstylus without ridge (Fig. 13E).

Etymology: The new genus is named after the former genus Pelecocera from which it is separated, with prefix pseudo from the ancient Greek word pseudēs meaning pretending or having a close resemblance. The name is to be considered as feminine.

\section{PeleCoCERA Meigen, 1822}

\section{CHAMAESYRPHUS MIK, 1895 STAT. NOV.}

The ML analyses of the three-genes and combined data sets (Figs 2,3) resolved the type species of genus Pelecocera (P. tricincta) as sister group to Palaearctic taxa of the subgenus Chamaesyrphus. This result is congruent with the results of the study of Ståhls et al. (2004) on a more limited taxon set (four species in total). There is no clear molecular and morphological evidence for treating these taxa as separate genera (Table 2). Our results support a division of the Palaearctic taxa of the clade into two subgenera, the nominal subgenus

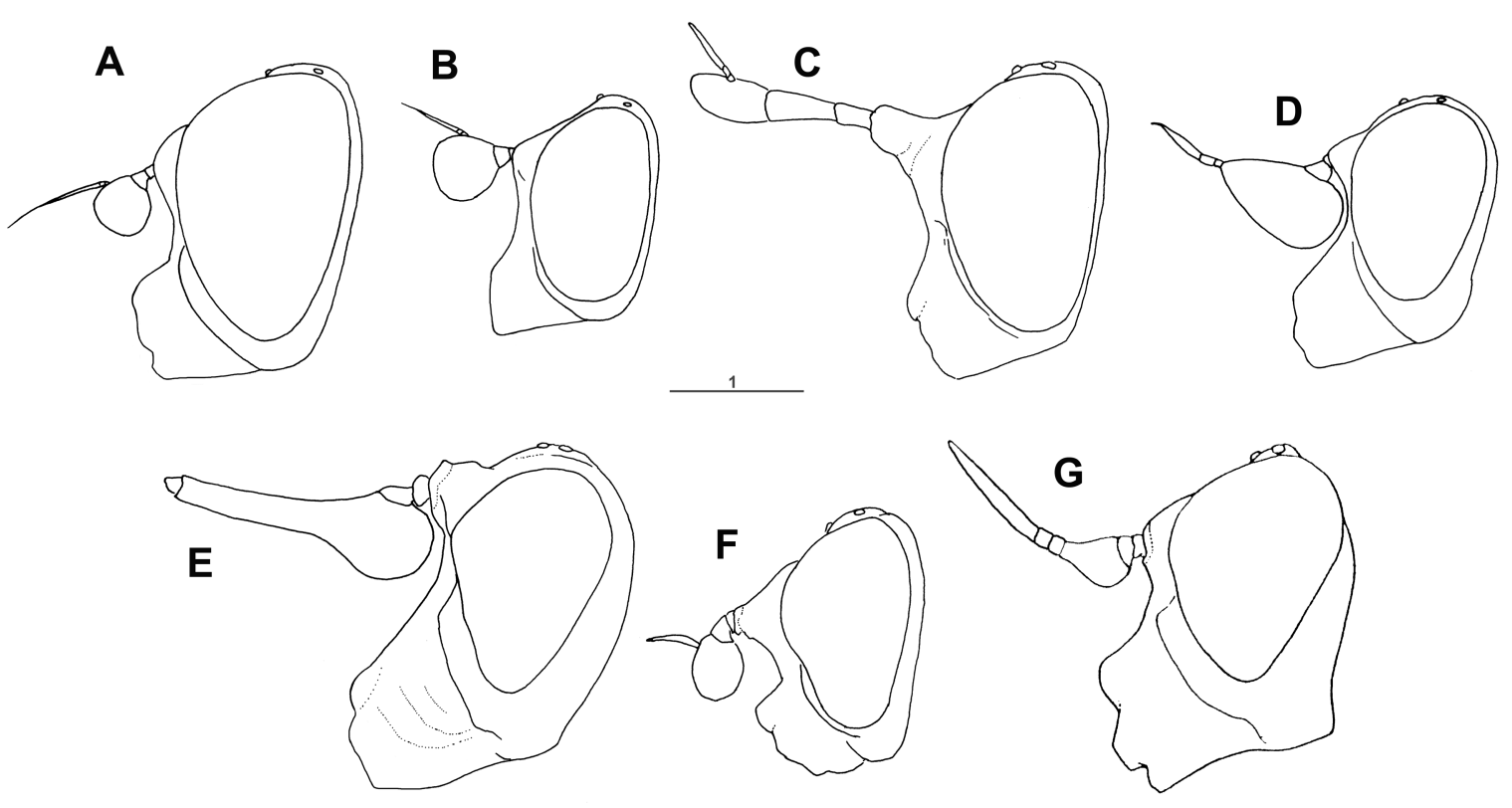

Figure 10. Male head, lateral view. A, Portevinia Goffe, 1944; B, Pelecocera (Chamaesyrphus) scaevoides (Fallen, 1817); C, Psarus Latreille, 1804; D, Pseudopelecocera latifrons (Loew, 1856); E, Macropelecocera Stackelberg, 1952; F, Psarochilosia Stackelberg, 1952; G, Ischyroptera bipilosa Pokorny, 1887. Scale in mm. 


\section{KEY TO RHINGIINI GENERA OCCURRING IN THE PALAEARCTIC REGION}

1. Basoflagellomere unmodified, with dorsal arista, which is thin and usually basal, never apical (Fig. 10A, B) ................................................................................................................. 4

- Basoflagellomere modified, usually with terminal style or a thick, apical arista (Fig. 10D, E, G)............. 2

2. Arista longer than basoflagellomere (Fig. 10G); frons less protruded (Fig. 10G); bristles on thorax present; alula of wing not narrow; subscutellar fringe present; eyes in male holoptic; gonostylus plate sinuous (as on Fig. 15C); spermal pump with lateral apodeme (as on 12D); distiphallus straight (as on Fig. 14I)............... Ischyroptera

- Arista shorter or as long as basoflagellomere (Fig. 10D, E); frons protruded (Fig. 10D, E); bristles on thorax absent; alula on wing narrow; subscutellar fringe absent; eyes in male dichoptic (Fig. 11A); gonostylus plate-like (Fig. 15D); spermal pump bifurcated (Figs 12F, G, 3D:e); distiphallus angulated (Fig. 14G) .....3

3. Lunula almost straight; striae on frons present (Fig. 11A); width of parafacia moderate (Fig. 10D); hypandrium elongate apically protruded (Fig. 13C); ejaculatory apodeme spatula-like (Figs 12F, 13D:f)

Pseudopelecocera gen. nov.

- Lunula normal, wavy; striae on frons inconspicuous; parafacia wider, hypandrium with usual shape, ejaculatory apodeme plate-like.

Macropelecocera

4. Head with a distinct frontal prominence (Fig. 10C, F)

- Head without a distinct frontal prominence (Fig. 10A, B) ............................................................6 6

5. Antenna modified, scapus and pedicel elongated (Fig. 10C); arista inserted beyond basal 1/3 (Fig. 10C); gonostylus sinuous (Fig. 15C); spermal pump bifurcated (Fig. 12C); basiphallus and distiphallus not forked (Fig. 14C) Psarus

- Antenna not modified (Fig. 10F); arista inserted before basal 1/3 (Fig. 10F); gonostylus elongate (Fig. 15F); spermal pump cap-like (Fig. 12I); basiphallus and distiphallus forked (Fig. 14H) ................Psarochilosia

6. Lunula very large (Fig. 11E); parafacia wide (Fig. 10A); eyes bare, in male dichoptic (Fig. 11E) ...... Portevinia

- $\quad$ Lunula of usual size (Fig. 7A-D); parafacia usually less wide (as on Fig. 10B, C) ................................. 7

7. Triangular excavation on proepisternum of propleuron present (Fig. 16A:p); ejaculatory apodeme mostly slender (stick-like) (Fig. 12D, E); lateral sclerites of distiphallus partly fused

Cheilosia

- Triangular excavation on proepisternum of propleuron absent (Fig. 16B); ejaculatory apodeme spatula-like (Fig. 6C:f) or fan-like (Fig. 12B, H); lateral sclerites of distiphallus fused (Figs 6C, 14D) or free (Fig. 14B, F)

8. Antennal pits confluent (Fig. 7C); metasternum hairy; alula of wing not reduced; eyes in male holoptic ...... 10

- Antennal pits narrowly connected (Fig. 7A); metasternum bare; alula of wing reduced (Fig. 8A:x); eyes in male dichoptic (Figs 4D, 11B, C)

9. Aristal insertion before basal 1/3 (Fig. 4C); lunula almost straight (Fig. 7A); frons protruded (Fig. 4A); striae on frons present (Fig. 4D); bristles on thorax absent; proepisternum bare; ejaculatory apodeme spatula-like (Fig. 6C:f); lateral sclerites of distiphallus fused (Fig. 6C); lateral arms of minis not well developed (Fig. 6B:g)

Katara gen. nov.

- Aristal insertion beyond basal 1/3 (Fig. 10B); lunula as on Fig. 7C; frons not protruded (Fig. 10B); striae on frons absent (Fig. 11B, C); bristles on thorax present; proepisternum hairy; ejaculatory apodeme fanlike (Fig. 12B, H); lateral sclerites of distiphallus free (Fig. 14B, F); lateral arms of minis divided apically (Fig. 17C)

Pelecocera

10. Oral margin elongated into a long snout; eyes pilose; frons not protruded; tergites 3 and 4 with lateral margins; ejaculatory apodeme fan-like (Fig. 12J); basiphallus not dentate and not forked (as on Fig. 14I) Rhingia

- Oral margin not elongated into a long snout; eyes bare; frons protruded; tergites 3 and 4 without lateral margins; ejaculatory apodeme spatula-like; basiphallus dentate and forked (Fig. 14D) ...........Ferdinandea

Pelecocera and subgenus Chamaesyrphus. The main morphological character distinguishing these subgenera is the shape of phallus, divided in basi- and distiphallus in Chamaesyrphus (Fig. 14B) and fused in Pelecocera (Fig. 14F). In the COI gene tree the Nearctic species Pelecocera willistoni was resolved as sister to all Peleococera (including Chamaesyrphus) (Fig. 1). To establish the phylogenetic placement of the Nearctic Pelecocera taxa, additional character and taxon sampling is necessary. 

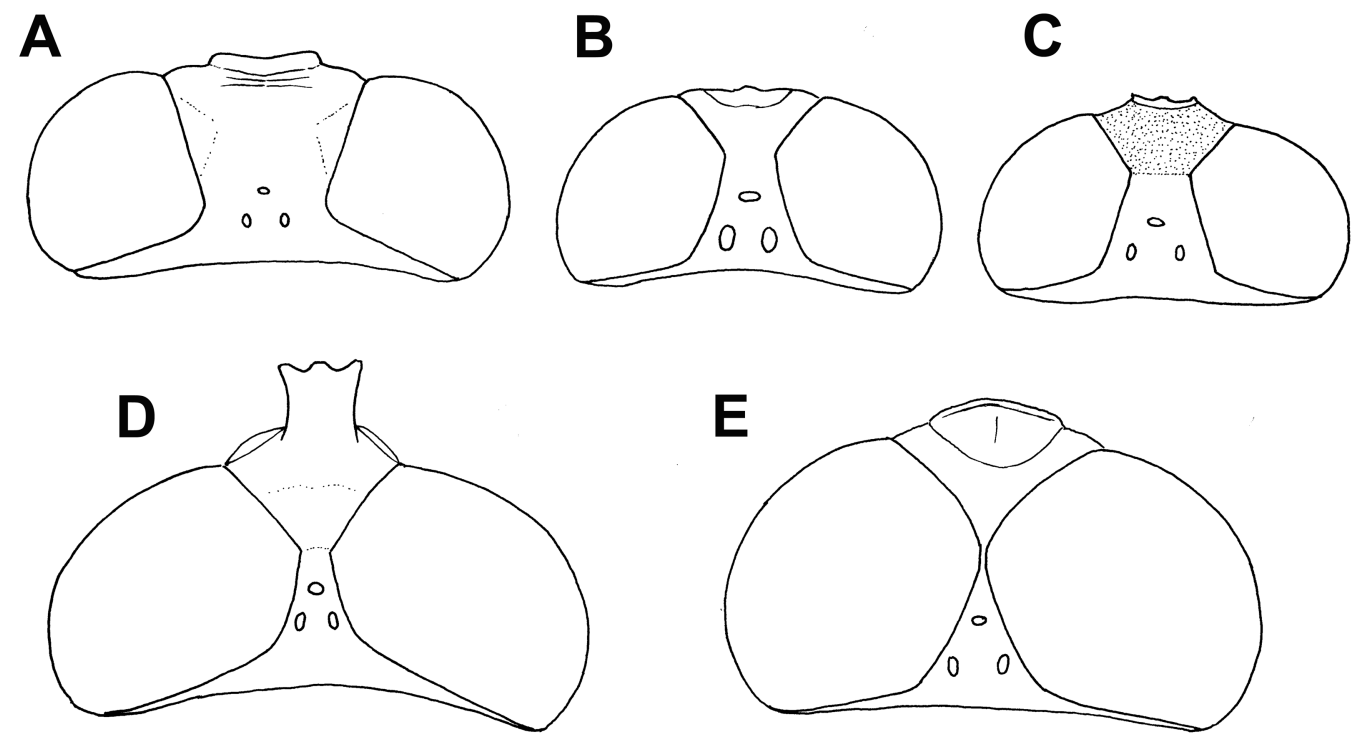

1

Figure 11. Male head, dorsal view. A, Pseudopelecocera latifrons (Loew, 1856); B, Pelecocera tricincta Meigen, 1822; C, Pelecocera (Chamaesyrphus) scaevoides (Fallen, 1817); D, Psarus Latreille, 1804; E, Portevinia Goffe, 1944. Scale in mm.

\section{DISCUSSION}

\section{PhyLOGENETIC AFFINITIES AND PLACEMENTS OF RHINGIINI GENERA}

Ståhls et al. (2004) included a large number of Cheilosia species in their molecular and combined genes+morphology phylogenetic analyses, but a lower number of other representatives of Rhingiini. Their results suggested that Pelecocera latifrons is not a member of the genus Pelecocera, and this result is supported by the present study (with a larger representation of Rhingiini taxa and a more limited set of Cheilosia species). In the different analyses (parsimony, optimisation alignment with different character weighting schemes) conducted by Ståhls et al. (2004), Pelecocera latifrons was resolved either in a basal polytomy or as sister taxon to Macropelecocera.

Our phylogenetic analyses consistently resolved Katara gen. nov. and Pseudopelecocera gen. nov. as sister taxa (Figs 2,3). These taxa share the following characters: narrowly connected antennal pits and almost straight dorsal margin of lunula; presence of conspicuous striae on frons; hypandrium of male genitalia apically protruded. Katara gen. nov. exhibits a combination of diagnostic characters clearly different from Pseudopelecocera gen. nov. (Table 3) supporting the valid generic status of both taxa.

The three-genes analysis resolved genus Portevinia as sister to genus Pelecocera (Fig. 2, bootstrap support $79 \%$ ), while the combined analysis placed the taxon as sister to Pseudopelecocera gen.nov. + Katara gen.nov., but lacking support (Fig. 3). Genus Portevinia shares with Pseudopelecocera gen. nov., Macropelecocera and Katara gen. nov.the following character states: narrowly connected antennal pits, reduction of alula, and similar shapes of the spermal pump and gonostylus (Figs 4C, 6C:e, 6D, 8A, 8C:x, 10A, 10E, 12A, 12G, 15A). Many characters of Katara gen. nov. are similar to those of the genus Portevinia such as the shape of antennae (Figs $4 \mathrm{~A}, 10 \mathrm{~A}$ ), vein $R_{4+5}$ meeting the costal vein before the tip of wing (Fig. 8A:y), similarly reduced alula of wing (Fig. 8A, C), and the same type of aedeagus (Figs 6C, 14A). Genus Portevinia was previously variously classified as a member of the subtribe Cheilosiina (Thompson, 1972) or Psarina (Shatalkin, 1975). The taxon has many key characters in common with the other genera of tribe Rhingiini, e.g. eyes bare, antennal pits confluent, partly reduced alula (Fig. 8C), and gonostylus with developed ctenidium (Fig. 15A).

Genera Pseudopelecocera gen. nov., Macropelecocera and Katara gen. nov. also share with the genus Psarus the dichoptic eye in male, a reduced alula and a similarly shaped spermal pump (Figs 4D, 6C:e, 11A, 12C, $12 \mathrm{~F}, 12 \mathrm{G}, 13 \mathrm{D}: \mathrm{e})$, but there are not resolved together in our analyses (Figs 2, 3).

Katara gen. nov. shares some important characters (dichoptic eyes in both sexes, bare metasternum, more or less reduced alula and structure of male genitalia) individually with several other genera (Table 2).

Genus Cheilosia exhibits the highest number of apomorphic characters (triangular excavation present on proepisternum of propleuron, lateral sclerites of 

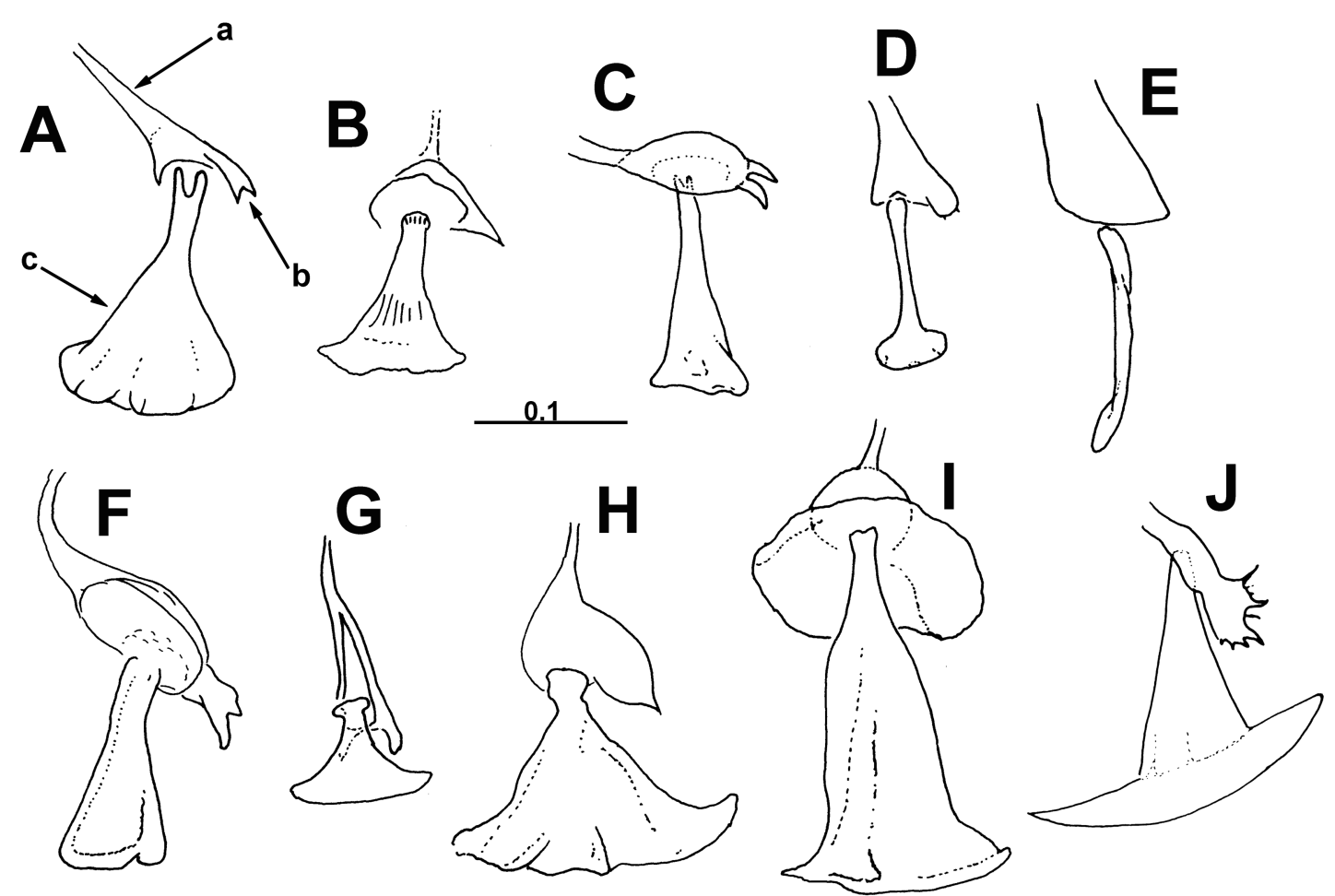

Figure 12. Parts of ejaculatory complex. A, Portevinia Goffe, 1944; B, Pelecocera (Chamaesyrphus) scaevoides (Fallen, 1817); C, Psarus Latreille, 1804; D, Cheilosia laticornis (Rondani, 1857); E, Cheilosia (Hiatomyia) (Shannon, 1922); F, Pseudopelecocera latifrons (Loew, 1856); G, Macropelecocera Stackelberg, 1952; H, Pelecocera tricincta Meigen, 1822; I, Psarochilosia Stackelberg, 1952; J, Rhingia (Eorhingia) (Hull, 1949). Abbreviations: a, ejaculatory duct; b, spermal pump; c, ejaculatory apodeme. Scale in $\mathrm{mm}$.

distiphallus partly fused and ctenidium on gonostylus reduced) (Table 2). Cheilosia is characterized by high morphological character variability and an exceptional diversity of taxa, with 446 described species worldwide (Ståhls \& Barkalov, 2017). The ML analyses resolved the genus Cheilosia as monophyletic with high bootstrap support (Figs 2, 3).

The only synapomorphy in common to all genera except Cheilosia is the angulated shape of the distiphallus. The morphologically most distinct genus within Rhingiini is Ferdinandea, which is different from all other taxa in the following combination of characters: metasternum bare, males dichoptic (or eyes meeting at one point, as in Portevinia); alula reduced; eyes bare (all these characters are the opposite in Ferdinandea). Here, the studied Palaearctic and Neotropical taxa of the genus Rhingia were resolved as one clade, and selected Afrotropical Rhingia taxa, including Rhingia (Eorhingia) cuthbertsoni, as its sister clade. The Afrotropical $R$. (E.) cuthbertsoni has dichoptic eyes in males, while the other Afrotropical taxa are holoptic. A possible subgeneric division of the genus deserves a separate study also including representatives also from the Oriental region which has the greatest species abundance (Thompson, 1972), and additional samples from the New World, which was beyond the scope of the present paper.

\section{RHINGIINI: SUBTRIBAL CLASSIFICATION}

The previously proposed divisions of tribe Rhingiini into subtribes (Thompson, 1972; Shatalkin, 1975) was not supported by the molecular and morphological results of Ståhls et al. (2004). Thompson (1972) distinguished two subtribes - Cheilosiina (comprising the genera Cartosyrphus Bigot, 1883, Cheilosia, Ferdinandea, Hiatomyia, Portevinia, Psarochilosia and Rhingia) and Pelecocerina (comprising Chamaesyrphus, Ischyroptera, Macropelecocera and Pelecocera) within the tribe Rhingiini, but with unplaced genus Psarus. Shatalkin (1975) classified the tribe Rhingiini into three subtribes: Psarina (Ferdinandea, Rhingia, Portevinia and Psarus), Pelecocerina (Chamaesyrphus, Pelecocera and Macropelecocera) and Cheilosiina (Cheilosia, with three subgenera Cheilosia, Hiatomyia and Nigrocheilosia Shatalkin, 1975) based on the structure of the male genitalia. The main clades resolved in the ML trees presented here (Figs 2,3), do not agree 

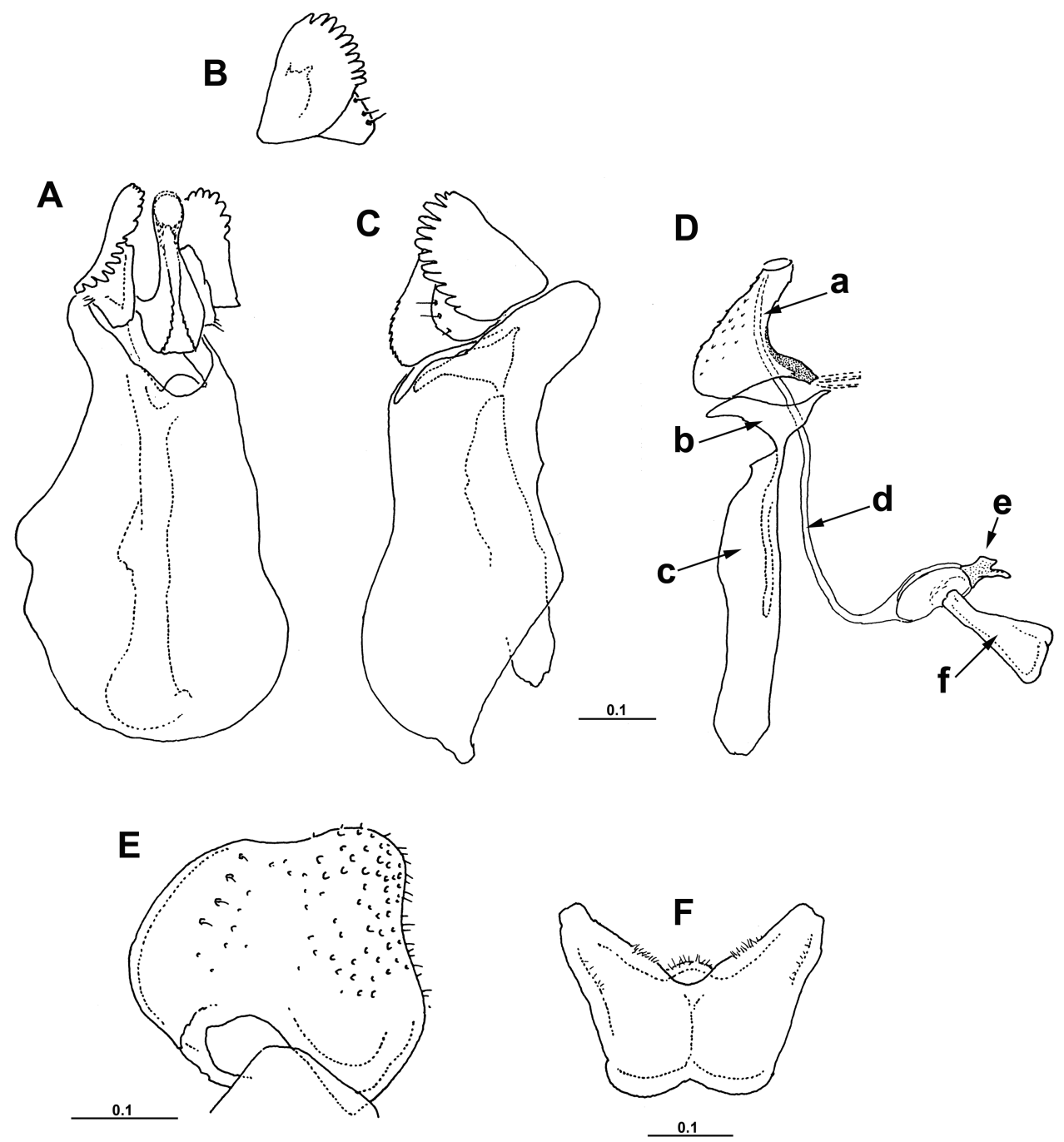

Figure 13. Pseudopelecocera latifrons (Loew, 1856), male genitalia. A, hypandrium, ventral view; B, gonostylus, lateral view; C, hypandrium, lateral view; D, phallus, lateral view; E, surstylus; F, minis. Abbreviations: a, distiphallus; b, basiphallus; c, phallapodeme; d, ejaculatory duct; e, spermal pump; f, ejaculatory apodeme. Scale in mm.

with the previously proposed subtribal divisions of Shatalkin (1975) or Thompson (1972). Ståhls et al. (2004) resolved Rhingia+Cheilosia as sister groups in several of their analyses (parsimony analysis of only COI sequences, parsimony analysis of adult morphological characters+two genes under both dynamic alignment and static alignments), agreeing with the present results of three-genes and combined data analysed under ML. Ståhls et al. (2004) resolved Psarus + Psarocheilosia as sister taxa, and Pelecocera as monophyletic in their different analyses, but Portevinia and Macropelecocera were resolved in different positions. More recent studies including a very limited number of Rhingiini taxa (four in Mengual et al., 2015b; and three in Young et al., 2016) recovered the tribe Rhingiini as monophyletic but presented variable placements of the included taxa. To conclude, the monophyly of the tribe has not been questioned, but neither of the proposed subtribal classifications were supported in subsequent studies.

We found that the morphological characters studied herein among all Rhingiini taxa offer only limited information for a subtribal division (see Table 2). Our three-genes analysis and combined data set recovered all speciose Rhingiini genera as monophyletic with high bootstrap support, namely the genus Rhingia with two groups, comprising Palaearctic+Neotropical and Afrotropical taxa, respectively, the genus Cheilosia with its subgenera, Ferdinandea and Pelecocera with its subgenera (Figs 2,3). Phylogenetic analyses support the presence of three main lineages within the tribe: (1) genus Rhingia, (2) genus 


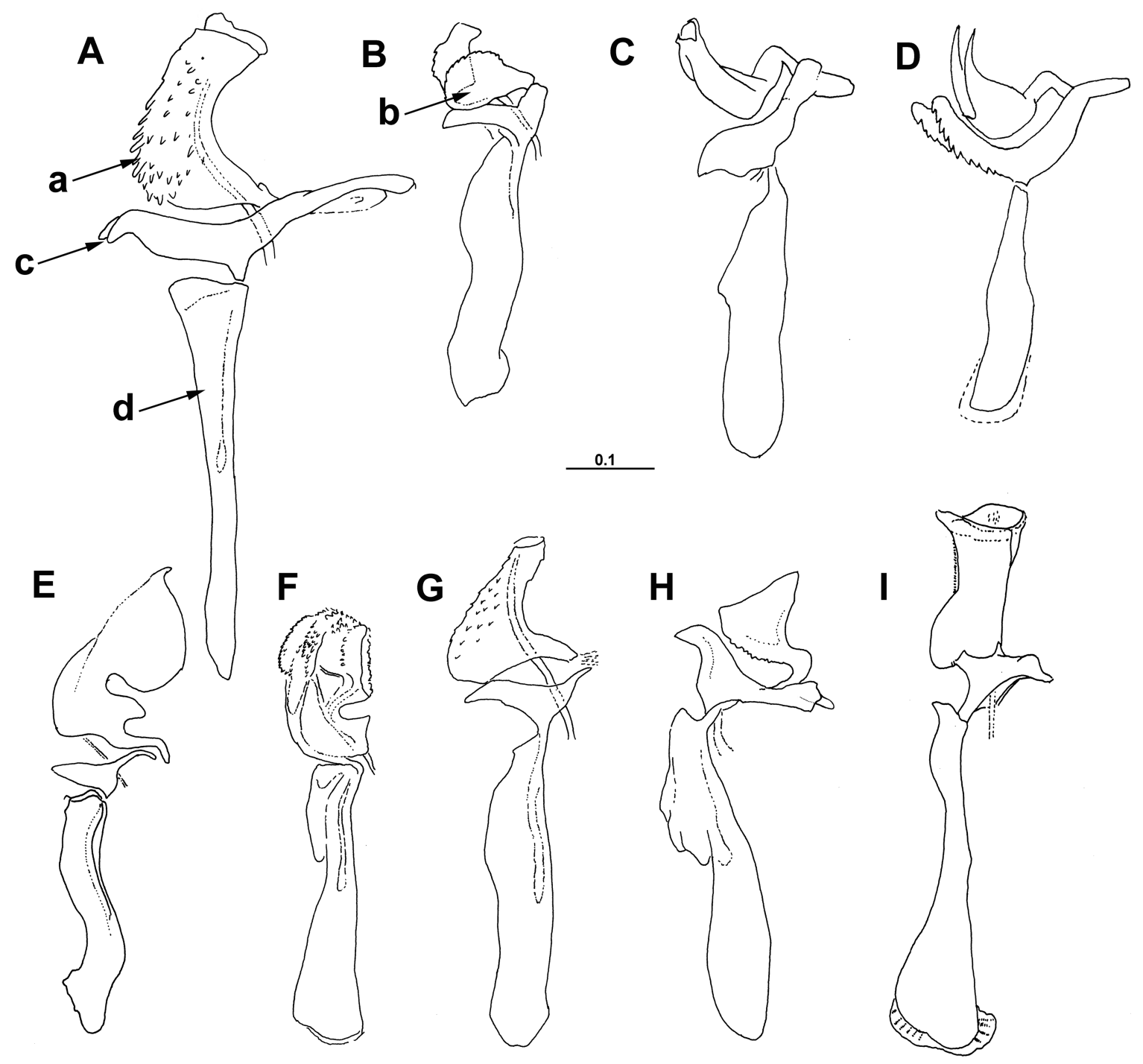

Figure 14. Aedeagus with phallapodeme, lateral view. A, Portevinia maculata (Fallen, 1817); B, Pelecocera (Chamaesyrphus) scaevoides (Fallen, 1817); C, Psarus abdominalis (Fabricius, 1794); D, Ferdinandea cuprea (Scopoli, 1763); E, Macropelecocera Stackelberg, 1952; F, Pelecocera tricincta Meigen, 1822; G, Pseudopelecocera latifrons (Loew, 1856); H, Psarochilosia Stackelberg, 1952; I, Cheilosia derasa Loew, 1857. Abbreviations: a, distiphallus; b, lateral sclerite of distiphallus; c, basiphallus; d, phallapodeme). Scale in mm.

Cheilosia, and (3) lineage with remaining genera (Pseudopelecocera gen. nov., Katara gen. nov., Ferdinandea, Psarochilosia, Psarus, Portevinia and Pelecocera). Macropelecocera and Ischyroptera are currently incertae sedis. We refrain from proposing a subtribal division of Rhingiini in the present study. In forthcoming studies at least Oriental taxa of the speciose genera of the tribe are necessary to include, as this region is the likely origin for most lineages, but material for molecular analyses has not been available.

\section{RHINGIINI: HIGH TAXONOMIC DIVERSITY}

Based on molecular and morphological evidence (e.g. Thompson, 1972, this study), the tribe Rhingiini is undoubtedly monophyletic. The tribe includes genera with remarkably high morphological variability and species richness (Table 1). Cheilosia is the most speciose hoverfly genus of the Syrphidae family (or next to it), comprising at least 446 species (Ståhls \& Barkalov, 2017) classified into thirteen subgenera (Barkalov, 2002, 2007). Numerous recent studies concerning the Cheilosia fauna of the Palaearctic region 

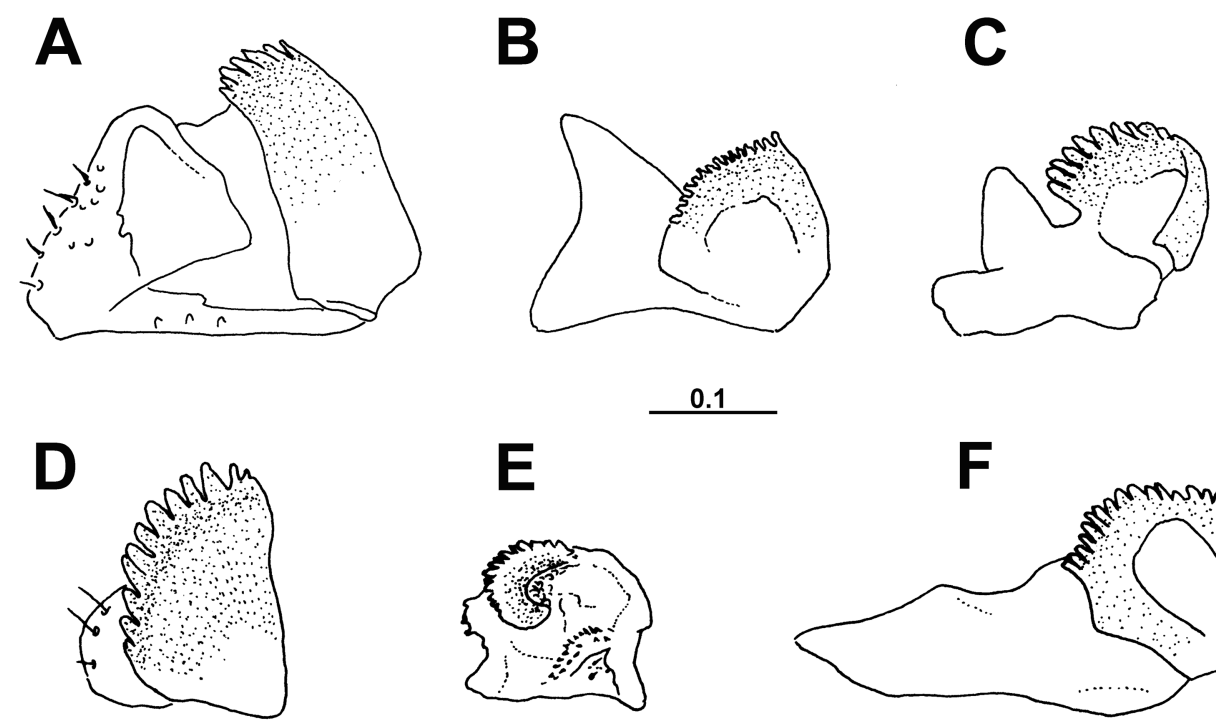

0.1
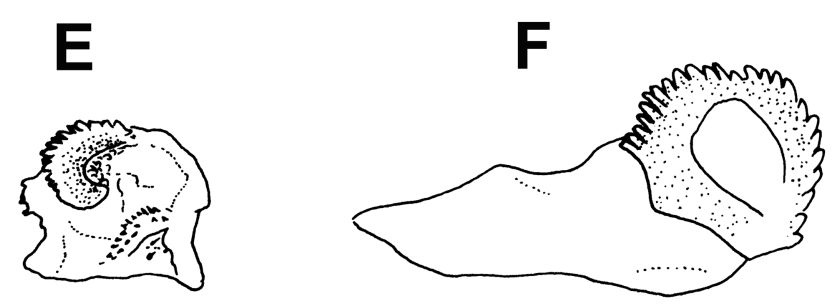

Figure 15. Gonostylus, lateral view. A, Portevinia Goffe, 1944; B, Pelecocera (Chamaesyrphus) scaevoides (Fallen, 1817); C, Psarus Latreille, 1804; D, Pseudopelecocera latifrons (Loew, 1856); E, Pelecocera tricincta Meigen, 1822; F, Psarochilosia Stackelberg, 1952. Scale in $\mathrm{mm}$.

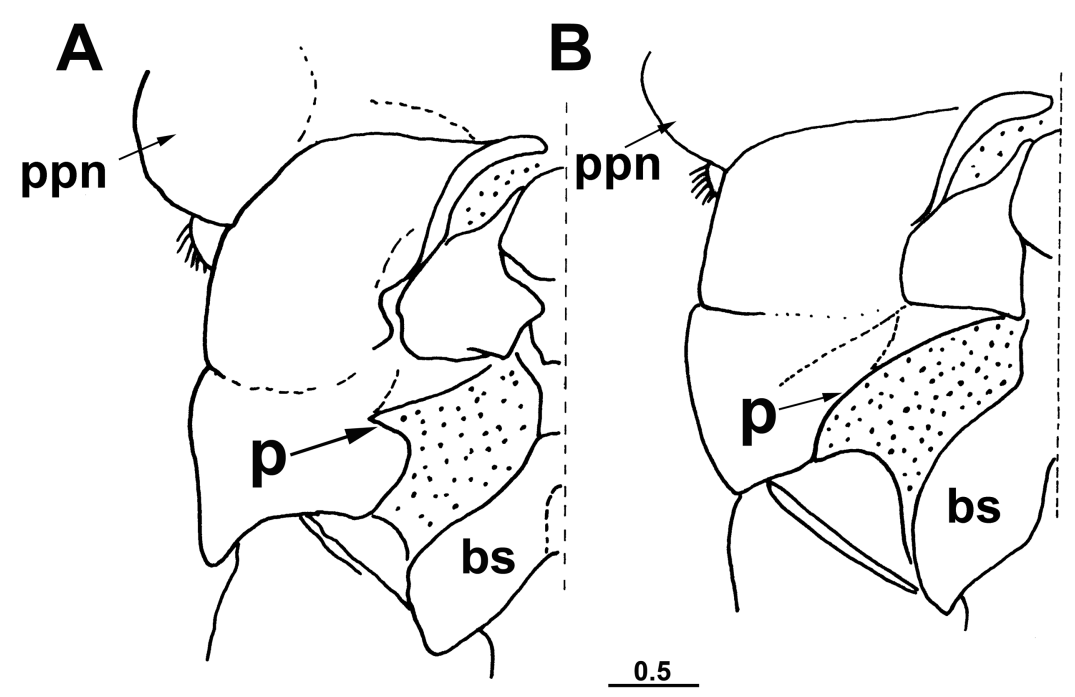

Figure 16. Thorax, anterior view. A, Cheilosia Meigen, 1822; B, Portevinia Goffe, 1944. Abbreviations: p, inner margin of proepisternum of propleuron; ppn, postpronotum; bs, protoracic basisternum. Scale in mm.

have continued to add new taxa to the genus (e.g. Claussen, 2000; Barkalov \& Cheng, 2004; Claussen \& Ståhls, 2007; Vujić et al., 2013; Barkalov \& Ståhls, 2015). Rhingia, Pelecocera, and Ferdinandea are genera with wide distributions and moderately high numbers of species (Table 1), but with few recent descriptions of taxa new to science (e.g. Kassebeer, 1999; Mutin \& Barkalov, 1999, Claussen \& Weipert, 2003). Portevinia is a genus with only four described species distributed in Palaearctic and Oriental regions. However, the Rhingiini tribe also comprises surprisingly many monotypic genera, namely Ischyroptera, Katara gen. nov., Psarochilosia and Psarus, three of which are long-recognized taxa. Of these monotypic genera three are distributed in isolated mountain ranges in the Palaearctic area, probably as relict taxa, being Ischyroptera in the Alps, Katara gen. nov. in Central Greek Mountains, and 

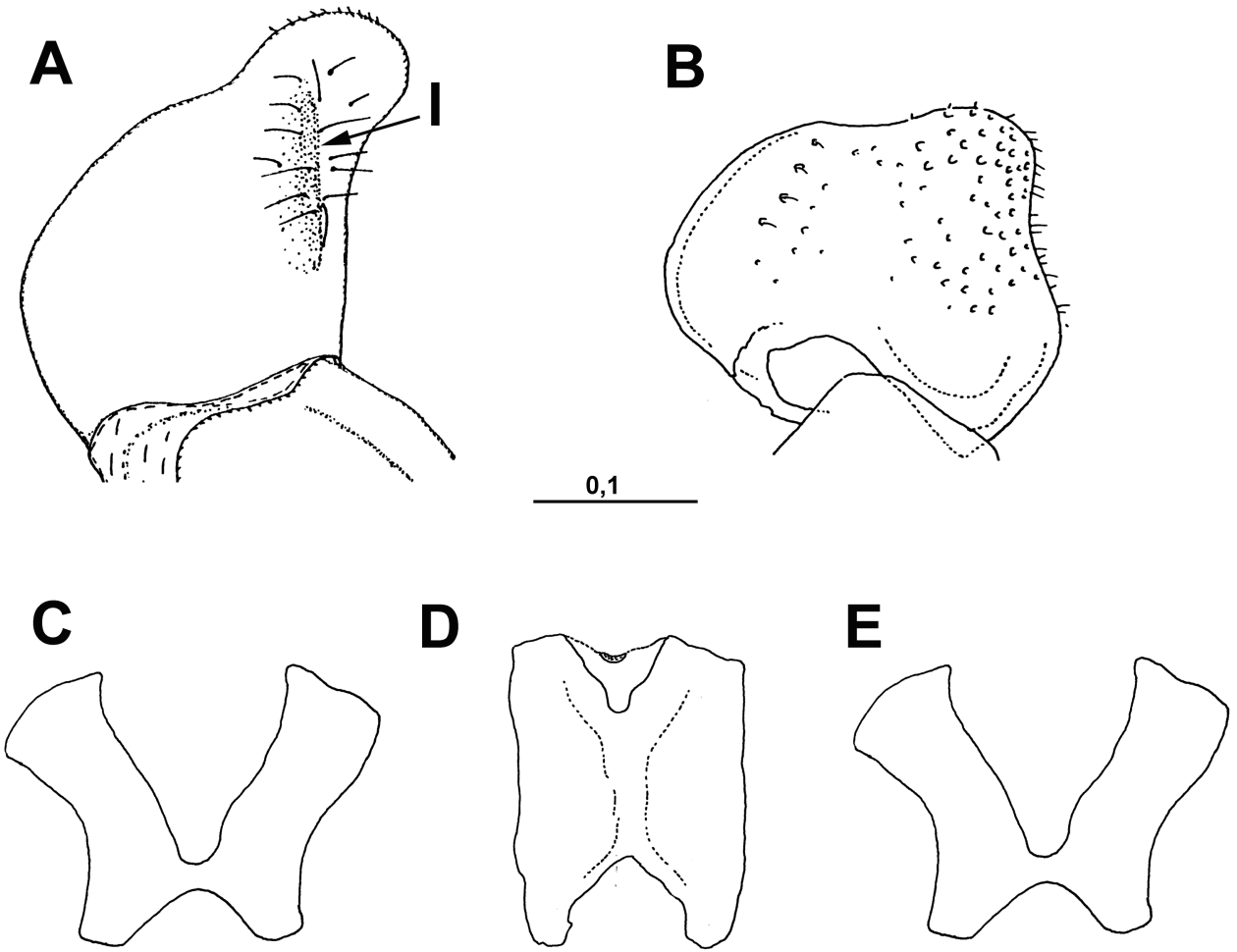

Figure 17. Parts of epandrium: surstylus (A-B), minis (C-E). A, Cheilosia morio (Zetterstedt, 1838); B, Pseudopelecocera latifrons (Loew, 1856); C, Pelecocera tricincta Meigen, 1822; D, Psarus abdominalis (Fabricius, 1794); E, Rhingia campestris Meigen, 1822. Abbreviation: 1, lateral carina. Scale in mm.

Table 3. Diagnostic morphological differences between Katara gen. nov. and Pseudopelecocera gen. nov.

\begin{tabular}{lll}
\hline & Katara gen. nov. & Pseudopelecocera gen. nov. \\
\hline 1 & Integument black without any trace of red or yellow marks & $\begin{array}{l}\text { Face in both sexes and male abdomen with yellow red- } \\
\text { dish marks } \\
\text { Narrow abdomen }\end{array}$ \\
2 & Body stocky, abdomen broad (Fig. 5E, F) & Clear sexual dimorphism \\
3 & Both sexes very similar in morphology & Antennae strongly modified (Fig. 10D) \\
4 & Antennae unmodified (Fig. 4C) & Face protruded (Fig. 10D) \\
5 & Face not protruded (Fig. 4A) & $\begin{array}{c}\text { Arista inserted beyond basal third (Fig. 10D) } \\
\text { Costal vein ending beyond wing apex }\end{array}$ \\
7 & Arista inserted before basal third (Fig. 4C) & Male genitalia: surstylus and hypandrium short, aeda- \\
8 & Costal vein ending before wing apex & gus and minis with different shape (Fig. 13)
\end{tabular}

Psarochilosia in the Russian Far East. Species of the genus Macropelecocera, M. paradoxa Stackelberg, 1952, M. pulchella Kuznetzov, 1990, M. sanguinea, and M. stackelbergi Kuznetzov, 1990 have similar types of restricted distributional ranges; $M$. paradoxa in Russian high mountains, M. pulchella in Kazakstan, M. sanguinea in mountains in Kyrgyz
Republic, and M. stackelbergi in Tajikistan. Psarus is widely distributed in lowland areas in Central and South Europe (reviewed in Mengual \& Ssymank, 2015). Pseudopelecocera gen. nov. comprises two known species from remotely situated areas; $P$. latifrons in the Eastern Palaearctic, Central Europe and Lebanon, and P. persiana with a distribution in Iran. 


\section{CONSERVATION}

Katara connexa gen. et sp. nov. and Psarus abdominalis (Fabricius, 1794) are rare and unique species and hence may become extinct in the wild. Both taxa are endemic to Europe. Psarus abdominalis has long been known from many localities in Europe, but is rare across its entire distributional range (Mengual \& Ssymank, 2015).The discovery of Katara connexa sp. nov. from Pindos Mountains in Greece is a remarkable finding from a European perspective, given that it has been more than 30 years since the last two new European hoverfly genera were described (Cryptopipiza Mutin, 1998, a new name for Pseudopipiza Violovitsh, 1985; and Primoceroides Violovitsh, 1985) and, prior to those, it was in the first half of the 20th century that the next most recent genus was discovered (Rohdendorfia Smirnov, 1924). Appropriate conservation measures to protect Katara connexa sp. nov. highlight the importance of nature conservation in Greece and in particular the protection of the mountainous habitats of the PindosMountains. These habitats harbor numerous glacial relict species, with Katara connexa sp. nov. and Cheilosia katara as significant representatives of the Syrphidae (Diptera).

\section{ACKNOWLEDGEMENTS}

We are sincerely grateful to National Museum of Natural History; Smithsonian Institution, Washington DC, USA (USNM) for loan of specimen of Ischyroptera bipilosa necessary to complete the present study. We thank Claus Claussen (Flensburg, Germany) for his valuable comments and support. This work was funded by projects of the Ministry of Education, Science and Technological Development of the Republic of Serbia (OI173002 and III43002) and The Provincial Secretariat for Higher Education and Scientific Research of the Republic of Serbia ("Evaluation of Ecological Networks in AP Vojvodina as support for nature conservation"). We thank Menno Reemer (Leiden, Netherlands), Ximo Mengual and Axel Ssymank (Bonn, Germany) for providing some species of Rhingiini for molecular work, and Jeff Skevington (Ottawa, Canada) for permission to use CNC barcode sequences. We are grateful to John O’Brien for English proofreading.

\section{REFERENCES}

Barkalov AV. 2002. Subgeneric classification of the genus Cheilosia Meigen, 1822 (Diptera, Syrphidae). Entomological Review 82: 518-531.
Brakalov AV. 2007. A new species, a new synonym, and new records of the hover-fly genus Cheilosia Meigen (Diptera, Syrphidae). Entomological Review 87: 368-375.

Barkalov AV, Cheng X-Y. 2004. Revision of the genus Cheilosia Meigen, 1822 (Diptera: Syrphidae) of China. Contributions on Entomology, International 5: 266-421.

Barkalov AV, Ståhls G. 2015. Descriptions of three new species of the genus Cheilosia Meigen from China (Diptera, Syrphidae). Zootaxa 3972: 280-290.

Claussen C. 2000. Eine neue Art der Gattung Cheilosia Meigen, 1822 (Diptera, Syrphidae) aus Bulgarien und ihre Verwandtschaftsbeziehungen. Volucella 5: 1-14.

Claussen C, Vujić A. 1993. Cheilosia katara n. sp. aus Zentralgriechenland (Diptera: Syrphidae). Entomologische Zeitschrift 103: 341-346.

Claussen C, Weipert J. 2003. Zur Schwebfliegenfauna Nepals (Insecta: Diptera: Syrphidae) unter besonderer Berücksichtigung Westnepals. In: Hartmann M, Baumbach H, eds. Biodiversität und Naturausstattung im Himalaya. Erfurt: Verein der Freunde und Förderer des Naturkundemuseums Erfurt e. V., 343-380.

Claussen C, Ståhls G. 2007. A new species of Cheilosia Meigen from Thessaly/Greece, and its phylogenetic position (Diptera, Syrphidae). Studia Dipterologica 3: 275-281.

Doczkal D. 2002. Description of Macropelecocera sanguinea spec. nov. from Kirghizia (Diptera, Syrphidae). Volucella 6: 45-51.

Folmer O, Black M, Hoeh W, Lutz R, Vrijenhoek R. 1994. DNA primers for amplification of mitochondrial cytochrome c oxidase subunit I from diverse metazoan invertebrates. Molecular Marine Biology and Biotechnology 3: 294-299.

Kassebeer CF. 1999. Eine neue Art der Gattung Ferdinandea Rondani, 1844 (Diptera, Syrphidae) aus Nordafrika. Beitrage zur Schwebfliegen Marokkos 9, Dipteron 2: 153-162.

Katoh K, Kuma K, Toh H, Miyata T. 2005. MAFFT version 5: improvement in accuracy of multiple sequence alignment. Nucleic Acids Research 33: 511-518.

Katoh K, Asimenos G, Toh H. 2009. Multiple alignment of DNA sequences with MAFFT. In: Posada D. ed. Methods in Molecular Biology. Bioinformatics for DNA Sequence Analysis. New York: Springer, Humana Press, 39-64.

Kuznetzov SY. 1989. Hover-flies of the genus Pelecocera Mg. (Diptera, Syrphidae). Latvijas Entomologs 32: 80-85.

Lewis PO. 2001. A likelihood approach to estimating phylogeny from discrete morphological character data. Systematic Biology 50: 913-925.

Mengual X, Ssymank A. 2015. New records of Psarus abdominalis (Fabricius) (Diptera: Syrphidae), a threatened species in Europe. Annales de la Société entomologique de France (N.S.) 51: 197-207.

Mengual X, Ståhls G, Rojo S. 2008. First phylogeny of predatory flower flies (Diptera, Syrphidae, Syrphinae) using mitochondrial COI and nuclear 28S rRNA genes: conflict and congruence with the concurrent tribal classification. Cladistics 24: 543-562.

Mengual X, Kazerani F, Talebi AA, Gilasian E. 2015a. A revision of the genus Pelecocera Meigen with the description 
of the male of Pelecocera persiana Kuznetzov from Iran (Diptera: Syrphidae). Zootaxa 3947: 99-108.

Mengual X, Ståhls G, Rojo S. 2015b. Phylogenetic relationships and taxonomic ranking of pipizine flower flies (Diptera: Syrphidae) with implications for the evolution of aphidophagy. Cladistics 31: 491-508.

Miller MA, Pfeiffer W, Schwartz T. 2010. Creating the CIPRES Science Gateway for inference of large phylogenetic trees. Proceedings of the Gateway Computing Environments Workshop(GCE), 14 Nov. 2010, New Orleans, LA, 1-8.

Mutin VA, Barkalov AV. 1999. Family Syrphidae. In: Ler PA, ed. Key to the insects of Russian Far East, 6, Diptera and Siphonaptera. Valdivostok: Dal'nauka, 1-665.

Peck LV. 1988. Syrphidae. In: Soos A, Papp L, eds. Catalogue of Palaearctic Diptera. Budapest: Akad. Kiado, 11-230.

Reemer M, Ståhls G. 2013. Phylogenetic relationships of Microdontinae (Diptera: Syrphidae) based on molecular and morphological characters. Systematic Entomology 38: 661-688.

Rotheray GE, Gilbert FS. 1999. Phylogeny of Palaearctic Syrphidae (Diptera): evidence from larval stages. Zoological Journal of the Linnean Society 127: 1-112.

Shatalkin AI. 1975. A taxonomic analysis of the hover flies (Diptera, Syrphidae). II. Entomological Review 54: 127-134.

Simon C, Frati F, Beckenbach A, Crespi B, Liu H, Flook P. 1994. Evolution, weighting and phylogenetic utility of mitochondrial gene-sequences and a compilation of conserved polymerase chain-reaction primers. Annals of the Entomological Society of America 87: 651-701.

Stamatakis A. 2014. RAxML version 8: a tool for phylogenetic analysis and post-analysis of large phylogenies. Bioinformatics doi: 10.1093/bioinformatics/btu033. Available at: http://bioinformatics.oxfordjournals.org/content/ early/2014/01/21/bioinformatics.btu033.abstract. Accessed 16 November 2017.

Stuke J-H. 2000. Phylogenetische Rekonstruktion der Verwandtschaftsbeziehungen innerhalb der Gattung Cheilosia Meigen, 1822 anhand der Larvenstadien (Diptera: Syrphidae). Studia Dipterologica Suppl. 8: 1-118.

Ståhls G, Stuke J-H, Vujić A, Doczkal D, Muona J. 2004. Phylogenetic relationships of the genus Cheilosia and the tribe Rhingiini (Diptera, Syrphidae) based on morphological and molecular characters. Cladistics 20: 105-122.

Ståhls G, Barkalov AV. 2017. Taxonomic review of the Palaearctic species of the Cheilosia caerulescens-group (Diptera, Syrphidae). ZooKeys 662: 137-171.

Speight MCD. 1987. External morphology of adult Syrphidae (Diptera). Tijdschrift Voor Entomologie 130: 141-175.

Speight MCD. 2014. Species accounts of European Syrphidae (Diptera), 2014. Syrph the Net, the database of European Syrphidae. Dublin: Syrph the Net Publications 78, 321 .

Tamura K, Stecher G, Peterson D, Filipski A, Kumar S. 2013. MEGA6: molecular evolutionary genetics analysis version 6.0. Molecular Biology and Evolution 30: 2725-2729.

Thompson FC. 1972. A contribution to a generic revision of the Neotropical Milesinae (Diptera, Syrphidae). Arquivos de Zoologia 23: 73-215.

Thompson FC. 1999. A key to the genera of the flower flies (Diptera: Syrphidae) of the Neotropical Region including descriptions of new genera and species and a glossary of taxonomic terms. Contributions on Entomology, International 3: 319-378.

Thompson FC, Rotheray GE, Zumbado MA. 2010. Syrphidae. In: Brown BV, Borkent A, Cumming JM, Wood DM, Woodley NE, Zumbado MA. eds. Manual of Central American Diptera. Ottawa, Canada: NRC Research Press, 763-792.

Thompson FC, Rotheray G. 1998. Family Syrphidae. In: Papp L, Darvas B, eds. Contributions to a manual of Palaearctic Diptera (with species reference to flies of economic importance). Budapest: Science Herald, 81-139.

Vujić A, Radenković S, Trifunov S, Nikolić T. 2013. Key for European species of the Cheilosia proxima group (Diptera, Syrphidae) with a description of a new species. ZooKeys 269: 33-50.

Young AD, Lemmon AR, Skevington JH, Mengual X, Ståhls G, Reemer M, Jordaens K, Kelso S, Lemmon EM, Hauser M, Meyer MD, Misof B, Wiegmann BM. 2016. Anchored enrichment dataset for true flies (order Diptera) reveals insights into the phylogeny of flower flies (family Syrphidae). BMC Evolutionary Biology 16: 143. doi: 10.1186/ s12862-016-0714-0.

\section{SUPPORTING INFORMATION}

Additional Supporting Information may be found in the online version of this article at the publisher's web-site:

Table S1. Specimens used for morphological and molecular studies (including GenBank accession numbers). Appendix S2. Character state descriptions (character descriptions and states as in Ståhls et al. (2004) study with character number in boldface). 